\title{
Notice Versus Knowledge Under the Digital Millennium Copyright Act's Safe Harbors
}

\author{
Emily Zarins $\dagger$
}

\section{TABLE OF ConTENTS}

Introduction

I. Copyright Law in the Digital Realm: The Move Away from

Direct Infringement Liability ..................................................... 262

A. Early Calls for Direct Infringement Liability ......................... 262

B. A Critical Response to Direct Infringement Liability............... 265

C. Testing the Waters: Netcom Chips Away at Service

Provider Liability ................................................................. 268

II. The DMCA: Congress Adopts Netcom's Core Principles............... 269

A. The Underlying Competing Interests .................................... 269

B. Compromise in the DMCA ............................................... 27 I

C. Congress's Deliberate Distinction: Notice Versus

Knowledge

1. Notice Generates Duty to Investigate...................................... 274

2. Contrasting Knowledge for Purposes of Contributory

Infringement

III. Confusion in the Case Law: The Different Approaches Since

Congress Adopted Section 512

A. The Conflation of Knowledge and Notice ................................. 278

B. Independent Analysis of Knowledge and Notice.........................28 I

C. Hazy Analysis Somewhere in Between ...................................... 284

IV. Distinguishing Notice of Claim and Notice of Actual

Infringement

Copyright $\odot 2004$ California Law Review, Inc. California Law Review, Inc. (CLR) is a California nonprofit corporation. CLR and the authors are solely responsible for the content of their publications.

$\dagger \quad$ J.D. Candidatc, School of Law, University of California, Berkeley (Boalt Hall), 2004; A.B., Dartmouth Collcge, 1998. I would like to give special thanks to Professor Pamela Samuelson for generously providing inspiration, guidance, and cncouragement. I would also like to thank Kulpreet Rana for his business perspective, as well as Rebecca Hardiman, Tina Hulse, and other members of the California Law Review for their time and efforts in preparing this Comment for publication. Finally, my love and appreciation go to my family and friends for their constant support and enthusiasm. 
A. Shared Features of Knowledge for Contributory

Infringement and Notice for Safe Harbor Ineligibility .............. 286

B. Crucial Functional Differences Dwarf Similarities .................. 287

C. Framework for Analysis to Achieve Legislative Goals ............. 289

D. Benefits of Administering the Analytical Framework.............. 291

1. Upholding Due Process .................................................. 291

2. Protecting Free Speech ............................................... 292

E. Applying the Analytical Framework ..................................... 294

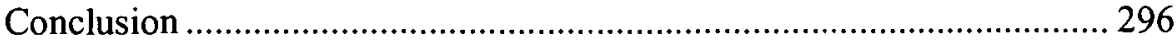




\title{
Notice Versus Knowledge Under the Digital Millennium Copyright Act's Safe Harbors
}

\author{
Emily Zarins
}

When Congress enacted the Digital Millennium Copyright Act (DMCA) in 1998, the cooperation of both Internet service providers and copyright owners was essential to realizing Congress's goal of expanding information exchange over the Internet. Therefore, Congress rejected proposals for direct infringement liability that threatened the viability of service providers and, instead, it created a notice-and-takedown scheme, which was inspired by the court's approach in Religious Technologies Center v. Netcom On-Line Communication Services, Inc. Section 512 of the DMCA provides safe harbors from liability for certain service providers, but copyright owners can warn a service provider of alleged infringement to commence a path to liability. Although section 512 's language and legislative history suggest that the purpose of a section 512 notification is predominantly to trigger an investigation of the alleged infringement by the service provider, courts have conflated such notification with the knowledge element of contributory copyright infringement.

This Comment proposes a framework for analysis that delineates between the knowledge requirement for contributory infringement and the notification requirements under section 512. By respecting the different functions of these requirements, this framework would better achieve legislative goals. The label "notice of claim" captures the preliminary, tentative nature of the service provider's knowledge after receipt of a notification of claimed infringement. In contrast, the label "notice of actual infringement" represents a knowledge that relates to an infringement that has already and actually occurred. Distinguishing between notice of claim and notice of actual infringement will ultimately protect not only due process, by giving service providers an opportunity to investigate copyright infringement claims described in notifications, but also free speech, by discouraging hasty takedowns of material based solely on a copyright owner's claim. 


\section{INTRODUCTION}

Warnings have power. Suppose a highway patrol officer pulls over a driver for speeding. Because the driver's speedometer is broken, the officer gives him a warning not to drive faster than the speed limit. The driver is thankful that he did not receive a bona fide ticket and drives more slowlyat least for a little while-after the warning. The driver's reduced speed indicates that the warning was effective. Even if the officer had no proof of the excessive speed, the warning still would have alerted the driver to a potential problem with his driving. That suspicion of unlawful driving, coupled with the awareness that highway patrol officers are monitoring his

speed and might issue a ticket next time he speeds, causes the driver to take greater care in the future.

On the "information superhighway" it is virtually impossible to monitor closely the thousands of files transmitted each second by millions of Internet users. Warnings of potential copyright liability, therefore, can be a useful tool to influence behavior and balance burdens. For this reason, Congress declined to hold Internet service providers ${ }^{i}$ strictly liable for copyright infringement. Instead, it decided to set up safe harbors from copyright liability in section 512 of the Digital Millennium Copyright Act (DMCA) in 1998. ' By allowing for an initial "512 warning," through which the copyright owner notifies the service provider of alleged infringements, Congress spared service providers the trouble of perpetually searching content. At the same time, Congress stimulated a safer environment for copyrights and provided some needed clarity regarding service providers' potential liability. ${ }^{3}$

Contrary to Congress's intention, however, the warning has become the bona fide ticket. Courts have used section 512 notifications from a copyright owner to the service provider to establish prematurely the knowledge element of contributory copyright infringement. ${ }^{4}$ Section 5 I2 notice and the knowledge element of contributory copyright infringement have similarities, but they are not the same. Both stem from the doctrine of

1. Congress focused on parties that provide "storage of material on a system or network controlled or operated by or for the service provider" as well as on parties that provide tools that refer or link users to online locations. See 17 U.S.C. § 512(b)-(d) (1998).

2. $\quad$ ld. $\S 512$.

3. See S. REP. No. 105-190, at 1 (1998) (noting that the DMCA "is designed to facilitate the robust development and world-wide expansion of electronic commerce, communications, research, development, and education").

4. See, e.g., Arista Records, Inc. v. MP3Board, Inc., No. 00 Civ. 4660, 2002 U.S. Dist. LEXIS $16165,{ }^{*} 24-* 30$ (S.D.N.Y. July 2, 2002); CoStar Group lnc. v. LoopNet, Inc., 164 F. Supp. 2d 688, 698-99 (D. Md. 2001). To be held liable for contributory copyright infringement, a third party must act with knowledge of the infringing activity to "aid the primary infringer in accomplishing his illegitimate activity." Melville B. Nimmer \& David Nimmer, 3-12 Nimmer on Copyright $\$ 12.04$ [A][2][a] (Matthew Bender \& Company, Inc.) (2003) [hereinafter Nimmer ON COPYRIGHT]. 
intermediary liability ${ }^{5}$ and both provide the copyright owner with some control over redress. However, the function that notice is meant to serve is unique in each context. Even though the presence of the safe harbor may "convolute[] the analysis of copyright infringement which, theoretically, should proceed in a straight line,"6 contributory infringement's independent knowledge requirement should not disappear. The safe harbor and liability for contributory infringement do not share "contiguous . . bounds."

The aim of issuing section 512 notice is to induce the service provider to search its pages for the allegedly infringing material. I call this "notice of claim" because the notification alerts the service provider to suspicious activity and, presumably, triggers an investigation. ${ }^{8}$ From the service provider's perspective, the infringement is only alleged at this point. ${ }^{9}$ Of course, the service provider can take down the material right away. As I discuss below, however, this seemingly convenient approach poses serious First Amendment issues. ${ }^{10}$

In contrast, the goal of the knowledge requirement in a contributory infringement action is to punish a defendant's willful ignorance of its association with actual copyright infringement. Thus, the knowledge requirement extends beyond mere suspicion and requires more than just the receipt of a 512 warning to establish a defendant's liability for contributory infringement. I call this "notice of actual infringement" because the service provider has actual or constructive knowledge of the general underlying infringement, based on notice beyond the word of the copyright owner.

By conflating safe harbor notice with contributory infringement knowledge, courts defeat the function of the carefully created safe harbors. Conversely, when courts honor the distinct functions of notice of claim and notice of actual infringement, they further Congress's desires to alleviate burdens on service providers and to promote the availability of copyrighted materials on the Internet. Furthermore, a bifurcated analysis protects service providers' right to due process and, consequently, protects free speech by eliminating takedowns based on an unwarranted fear of liability.

5. That is, both attempt to hold the service provider, as a third party, liable for its involvement in the infringing activity of another.

6. CoStar, 164 F. Supp. 2d at 699.

7. Id.

8. If the knowledge exceeds suspicion, and the service provider knows the material is infringing or is aware enough to infer that infringing activity is apparent, the safe harbor disappears. 17 U.S.C. $\S 512(\mathrm{c})(1)(\mathrm{A})(\mathrm{i})-(\mathrm{ii})$

9. The safe harbors give the service provider the opportunity to hedge its bets based on the results of its investigation. If it does not remove the material, it can no longer avail itself of a safe harbor. At that point, it will face a contributory infringement claim, and a court will evaluate whether its judgment regarding the validity of the underlying infringement was incorrect. This freedom of judgment may seek to promote free speech, but problems remain regarding technical employees' difficulty to judge confidently the legitimacy of material, which can lead to hasty takedowns. See infra notes 239-45 and accompanying text.

10. See infra Part IV.D.2. 
Part I of this Comment provides some historical context of the road to the DMCA safe harbors. Part II shows how, under Congress's compromise, a copyright owner's notice of claim serves as a warning mechanism that gives rise to a duty to investigate-quite a different function from knowledge for purposes of contributory infringement. Part III outlines the relevant case law and highlights the mixed approaches courts take when they analyze cases that involve both contributory infringement liability and notice pursuant to section 512 .

Lastly, Part IV discusses how delineating between, and analyzing separately, the knowledge requirement for contributory infringement and the notification requirements under section $5 \mathrm{I} 2$ will protect both due process and free speech. Part IV outlines a framework for analysis that will better achieve legislative goals by referring to a compliant section 5I2 notification as a "notice of claim." In contrast, a service provider that is ineligible for the safe harbor and found to have the requisite knowledge for contributory infringement possesses "notice of actual infringement" beyond a mere suspicion of wrongdoing.

\section{I}

Copyright Law in the Digital Realm: The Move Away from DIRECT INFRINGEMENT LIABILITY

\section{A. Early Calls for Direct Infringement Liability}

Copyright law seeks both to benefit the public and to protect crea-

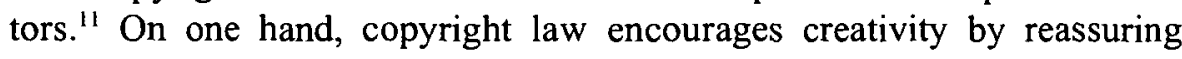

11. See Eldred v. Ashcroft, 123 S. Ct. 769,785 n.18 (2003). In the past, copyright law sought primarily to benefit the public; protecting creators was its secondary goal. See David N. Weiskopf, The Risks of Copyright Infringement on the Internet: A Practitioner's Guide, 33 U.S.F. L. REv. 1, 9 n.34 (1998). The House of Representatives stated:

Not primarily for the benefit of the author, but primarily for the benefit of the public, such [copyrights] are given. Not that any particular class of citizens, however worthy, may benefit, but because the policy is believed to be for the benefit of the great body of people, in that it will stimulate writing and invention to give some bonus to authors and inventors.

Id. (quoting H.R. REP. No. 60-2222, at 7 (1909) (report on the Copyright Act of 1909)) (alteration in original); see also id. at 9; Sony Corp. of Am. v. Universal City Studios, Inc., 464 U.S. 417, 429 (1984); Mazer v. Stein, 347 U.S. 201, 219 (1954). The Court in Sony moved to more of a middle ground when it stated:

The monopoly privileges that Congress may authorize are neither unlimited nor primarily designed to provide a special private benefit. Rather, the limited grant is a means by which an important public purpose may be achieved. It is intended to motivate the creative activity of authors and inventors by the provision of a special reward, and to allow the public access to the products of their genius after the limited period of exclusive control has expired. 464 U.S. at 429.

The Court very recently focused on the incentives of creators and seemed to move away from the idea that serving the public interest somehow takes precedence over protecting creators. Eldred, $123 \mathrm{~S}$. $\mathrm{Ct}$. at $785 \mathrm{n} .18$ (noting that "[ $\mathrm{t}$ ]he two ends are not mutually exclusive" and that "copyright law serves public ends by providing individuals with an incentive to pursue private ones"). The Court in Eldred quoted Mazer to state that " "[t]he economic philosophy behind the [Copyright] [C]lause ... is the conviction that encouragement of individual effort by personal gain is the best way to advance public 
creators that they will enjoy the fruits of their labor. On the other hand, copyright law limits creators' rights: after some time, society at large may exchange such creations freely. ${ }^{12}$

Congress has adapted this general concept in the face of technological innovations, most notably in 1976 to confront rapidly emerging technologies such as lasers, satellites, and various devices to store and retrieve information. ${ }^{13}$ Given that these advances in technology had "generated new industries and new methods for the reproduction and dissemination of copyrighted works, and the business relations between authors and users [had] evolved new patterns," Congress made various adjustments to recalibrate the balance between the public interest and creators' interests. ${ }^{14}$

Nearly two decades later, the advent of the lnternet introduced another technological revolution. The digital environment radically enhanced the potcntial to reproduce and redistribute original works easily and quickly. ${ }^{15}$ Moreover, the quality of those copies could be maintained even many generations downstream. ${ }^{16}$ In response, the Clinton Administration sought to formulate additional adjustments to copyright law to maintain the balance between the interests of the public and those of creators. ${ }^{17}$

President Clinton created the Information Infrastructure Task Force (IITF) in February 1993 to develop recommendations that would maximize the emerging information infrastructure's "tremendous potential" to enable education, global understanding, democratic participation, entertainment, and commerce. ${ }^{18}$ Accordingly, one of the IITF's working groups, the Working Group on Intellectual Property Rights, ${ }^{19}$ prepared a "Green

welfare through the talents of authors and inventors." Id. (quoting Mazer, 347 U.S. at 219) (alteration in original). The Court further explained that "'copyright law celebrates the profit motive ... [and] that the incentive to profit from the exploitation of copyrights will redound to the public benefit by resulting in the proliferation of knowledge... The profit motive is the engine that ensures the progress of science." Id. (quoting Am. Geophysieal Union v. Texaco Inc., 802 F. Supp. 1, 27 (S.D.N.Y. 1992)) (emphasis in original).

12. See U.S. ConST. art. $1, \S 8, \mathrm{cl}$. 8. The purpose of the clause was to "promote" knowledge, not to perpetuate copyrights. In fact, the Framers were reacting to a history in England of perpetual rights and censorship. See generally Mazer, 347 U.S. at 208-14 (summarizing the history of copyright laws); Marshall Leaffer, Understanding COPyright Law (2d ed. 1995). For a concise history of the events leading up to the drafting of Article I, Section 8, Clause 8 of the United States Constitution, see Glynn S. Lunney, Jr., The Death of Copyright: Digital Technology, Private Copying, and the Digital Millennium Copyright Act, 87 VA. L. REv. 813, 814-18 (2001).

13. H.R. REP. No. 94-1476, at 47 (1976).

14. Id.

15. Information Infrastructure Task Force Working Group on Intellectual Property Rights, Intellectual Property Rights and the National Information Infrastructure, 12, 14 (Sept. 1995), available at http:/www.uspto.gov/web/offiees/com/doc/ipnii/ipnii.pdf (last modified Nov. 15, 1995) [hereinafter White Paper].

16. Id. at 12 .

17. See id. at 14.

18. Id. at $1-14$

19. Bruce A. Lehman, Assistant Secretary of Commerce and Commissioner of Patents and Trademarks, served as the chair of the working group. Id. 
Paper" in July 1994 and a "White Paper" in September $1995 .{ }^{20}$ The working group aimed to "(1) ensure that users have access to the broadest feasible variety of works by (2) recognizing the legitimate rights and commercial expectations of persons and entities whose works are used in the [digital] environment."21

After analyzing existing copyright law and recognizing that the heralded potential of the digital age depended largely upon copyright owners' willingness to make their works available, the working group recommended a few changes to encourage copyright owners to contribute to the information infrastructure. ${ }^{22}$ One recommendation was to make service providers strictly liable for copyright infringements by users, ${ }^{23}$ given that service providers are "in a better position to prevent or stop infringement than the copyright owner" because they "are in the position to know the identity and activities of their subscribers and to stop unlawful activities."24 The working group suggested that service providers could, among other things, deny service to infringers or require subscribers to sign indemnification and warranty agreements to limit their liability. ${ }^{25}$

The White Paper cited two copyright cases to support its endorsement of direct liability: Playboy Enterprises, Inc. v. Frena and Sega Enterprises Ltd. v. MAPHIA.$^{26}$ In Playboy, a Florida district court found Frena, a bulletin board system (BBS) operator, directly liable for copyright infringement. ${ }^{27}$ Although it was Frena's subscribers who uploaded and downloaded unauthorized copies of Playboy's copyrighted photographs, the court held

20. Pamela Samuelson, The U.S. Digital Agenda at WIPO, 37 VA. J. INT'L L. 369, 379 (1997). A "green paper" is a preliminary report of government proposals that is published to stimulate discussion. A "white paper," on the other hand, is typically a government report with the purpose of educating industry customers.

21. White Paper, supra note 15 , at 13.

22. See id. at 17; Samuelson, supra note 20, at 379-80.

23. See White Paper, supra note 15, at 114-26.

24. Id. at 117. Jessica R. Friedman provides a list of the working group's reasons for advocating strict liability for service providers:

These reasons include the following: (1) online service providers are not the only ones who are in a position of being strictly liable without having the ability to screen the material that they handle 1sic] (e.g., neither can film developers) and who nevertheless have to pay this cost of doing business; (2) online service providers at least can take action when they are informed that infringement (allegedly) has occurred on their networks; (3) online service providers are the only ones who are in a position to know the identity of the subscriber who committed the infringement; (4) online service providers are making money from infringement when it occurs; (5) to incorporate an intent requirement into copyright law would make it much more difficult to prove infringement and therefore would undermine copyright protection as a whole; and (6) as between the copyright owner and the service provider, both relatively innocent parties, the preferable policy is to hold the service provider liable.

Jessica R. Friedman, A Lawyer's Ramble Down the Information Superhighway: Copyright, 64 FordHAM L. REv. 705, 722 n. 113 (1995).

25. White Paper, supra note 15, at 122-23.

26. Id. at $120-22$.

27. 839 F. Supp. 1552,1559 (M.D. Fla. 1993). 
Frena himself directly liable for infringing Playboy's distribution and public display rights. ${ }^{28}$ In line with the White Paper's direct liability approach, the court in Playboy noted that Frena's lack of awareness of the infringement was irrelevant because intent to infringe is not a required element to find infringement. ${ }^{29}$ Furthermore, Frena's claims that he removed the unauthorized photographs as soon as he became aware of their existence and proceeded to monitor the BBS to prevent further postings did not absolve him of liability. ${ }^{30}$

A few months later, in $M A P H I A$, a California district court issued a preliminary injunction against another BBS operator, who allegedly committed direct infringement by permitting a subscriber to upload copyrighted games onto the BBS. ${ }^{31}$ Although the facts in MAPHIA were arguably more sympathetic to the copyright owner than those in Playboy, ${ }^{32}$ this case further illustrates copyright law's initial inclination to hold service providers liable for direct infringement systematically, regardless of fault. ${ }^{33}$

\section{B. A Critical Response to Direct Infringement Liability}

As the White Paper's direct liability theory solidified in the contemporary case law, service providers and commentators began to question the wisdom of such an abrupt shift to a direct infringement regime and, instead, generally advocated a wait-and-see approach under the then-current

28. Id. at $1554-59$

29. Id. at 1559. While intent is not required to establish copyright infringement, a copyright owner must show "ownership of the copyright and "copying' by Defendant." Id. at 1556 (citing Feist Publ'ns, Inc. v. Rural Tel. Serv. Co., Inc., 499 U.S. 340 (1991); S. Bell Tel. \& Tel. Co. v. Associated Tel. Directory Publishers, 756 F.2d 801, 810 (11th Cir. 1985)).

30. See id. at 1554.

31. 857 F. Supp. 679, 683, 686-88, 690-91 (N.D. Cal. 1994), amended by 948 F. Supp. 923, 93136, 941 (N.D. Cal. 1996) (issuing a permanent injunction based not on direet infringement, but solely on a finding of inducement and contributory infringement).

32. See id. at 683 (noting that MAPHIA, the BBS operator, was acting for economic gain, had "particular[]" knowledge of the unauthorized uploading and downloading of Sega's works, and even solicited those unauthorized acts at times); 3-12B Nimmer ON COPYRIGHT, supra note 4, $\S 12 \mathrm{~B} .01[\mathrm{~A}][1]$.

33. See Mark A. Lemley, Peter S. Menell, Robert P. Merges \& Pamela Samuelson, SOFTWARE AND INTERNET LAW 888-91 (2000). Even in late 1997, district courts were imposing direct infringement liability on service providers. See, e.g., Playboy Enters., Inc. v. Webbworld, Inc., 991 F. Supp. 543 (N.D. Tex. 1997), aff'd, 168 F.3d 486 (5th Cir. 1999); Playboy Enters., Inc. v. Russ Hardenburgh, Inc., 982 F. Supp. 503 (N.D. Ohio 1997).

Some commentators supported the White Paper's contentions. See, e.g., Jane C. Ginsburg, Putting Cars on the "Information Superhighway": Authors, Exploiters, and Copyright in Cyberspace, 95 Colum. L. Rev. 1466, 1492-94 (1995); I. Trotter Hardy, The Proper Legal Regime for "Cyberspace", 55 U. PitT. L. Rev. 993, 1042-46 (1994); John Carmichael, Comment, In Support of the White Paper: Why Online Service Providers Should Not Receive Immunity from Traditional Notions of Vicarious and Contributory Liability for Copyright Infringement, 16 LoY. L.A. ENT. L.J. 759, 771-88 (1996). 
rules. ${ }^{34}$ Service providers and BBS operators recommended they " be held to a standard of liability based on contributory infringement, not one grounded on the strict standard of liability for direct infringement." 35 Service providers particularly had reason to wonder why the White Paper chose to omit seemingly relcvant case law that limited landlord liability for tenants' infringements. ${ }^{36}$ Those cases held that a landlord's power to inspect a tenant's premises or oversee a tenant's activities was too limited to justify liability. ${ }^{37}$ Likewise, service providers pointed out that their ability to monitor the "trillions of bits of data-representing millions of individual messages" that travel through their systems every day is virtually impossible without considerably slowing down the hailed "Internet speed" or burdening consumers with dramatically increased costs. ${ }^{38}$ Moreover, the Electronic Communications Privacy Act statutorily forbids service providers to search the storage "space" it rents out to users to store private material, including email. ${ }^{39}$ Therefore, not only was it virtually impossible for a service provider to monitor all the activities of each of its subscribers, it was either illegal or it seriously compromised the user's privacy interest. ${ }^{40}$

Commentators who questioned the need for an immediate clampdown on copyrights in the digital environment noted that the Internet was already experiencing "phenomenal growth" in available content; apparently, not all

34. See, e.g., Henry H. Perritt, JR., Law and the Information Superhighway 430-32 (1996) (noting that "an important missing ingredient" in the White Paper and early case law was First Amendment analysis); LANCE Rose, NetLaw: Your Rights in THE ONLINE World 91-92 (1995) (observing that Playboy Enterprises, Inc. v. Frena failed to address the chilling effect of holding service providers strictly liable for infringement without knowledge); Friedman, supra note 24, at 72324 (emphasizing the importance of considering the needs of users); Peter Jaszi, Caught in the Net of Copyright, 75 OR. L. REv. 299, 301 (1996) (advocating the preservation of "the special structures of copyright doctrine which exist to assure a reasonable level of public access even where copyrighted works are concerned, such as the doctrine of fair use"); Jessica Litman, Copyright in the Twenty-First Century: The Exclusive Right to Read, 13 CARDozo ARTs \& ENT. L.J. 29 (1994) (urging the Copyright Office to be just as concerned about an imbalance in the copyright bargain disfavoring the public as it is about an imbalance to the detriment of copyright owners); Pamela Samuelson, The Copyright Grab, 4.01 WIRED 135 (1996), at http://www.wired.com/wired/archive/4.01/white.paper_pr.html (last visited Sept. 17, 2003) (describing the Whitc Paper's copyright maximalist agenda generally, noting the value of allowing markets for eleetronic information delivery products and services to emerge so that any "legal fences" can be specifically tailored to "avert[ing] market failures," and observing that "[p]ushing through legislation mandating the maximalist vision before there is public consensus in support of it could baekfire by eroding the public's faith in the essential fairness of copyright law").

35. Friedman, supra note 24, at 722 (quoting Comments of Online Service Providers on a Preliminary Draft of the Report of the Working Group on Intellectual Property Rights 16 (Sept. 7, 1994)).

36. See Samuelson, supra note 34 .

37. See id.

38. Friedman, supra note 24, at 722 (quoting Comments of Online Service Providers on a Preliminary Draft of the Report of the Working Group on Intellectual Property Rights 12 (Sept. 7, 1994)).

39. See Samuelson, supra note 34 .

40. See id. 
content owners needed the reassurance of strengthened copyright law that the White Paper deemed a prerequisite to Internet content proliferation. ${ }^{41}$ The White Paper thus seemed to promote the interests of a block of copyright owners not yet on the Internet, ${ }^{42}$ even though the copyright laws originated partly to combat monopoly power of certain publishers. ${ }^{43}$

The effect of the White Paper's proposed changes would be not only to further the interests of powerful copyright holders, but also to call upon service providers to play the role of digital copyright cops. ${ }^{44}$ That is, faced with liability for direct infringement regardless of knowledge, a service provider could either close up shop or feverishly try to monitor all content flowing through its infrastructure through some centralized enforcement mechanism. ${ }^{45}$ Naturally, a threatened service provider that survives would be more compelled to overpolice rather than to underpolice and stand vulnerable to direct infringement claims.

Commentators brought to light some of the negative consequences of this overpolicing. Among other things, the White Paper's recommended regulatory regime of direct liability for service providers would chill speech, ${ }^{46}$ limit the Internet's promise of a diverse social dialogue, ${ }^{47}$ threaten public access to creative works, ${ }^{48}$ and increase the costs of accessing information. ${ }^{49}$ Commentators also exposed the White Paper's failure to consider seriously any interests other than those of copyright owners, an omission that inherently precluded any meaningful balancing of interests. ${ }^{50}$

Against this backdrop, Congress debated the issue of service provider liability in 1996 when it considered the National Information Infrastructure Copyright Protection Act, which captured various recommendations of the White Paper. ${ }^{51}$ However, Congress did not take any action on the proposed legislation. $^{52}$ In December 1996, Clinton administration officials introduced proposals similar to those in the White Paper at the World

41. See id.

42. See id.; Jaszi, supra note 34 , at 300-01 (noting that this restructuring not only is "privileging ... "content providers"" and their "continued economic well-being," but also "is putting at risk the principle of assured public access to the fruits of creativity which traditionally has been one of the pillars of our copyright system").

43. See Samuelson, supra note 34 (noting that "[w]hen the English Parliament passed the first modern copyright law, in 1710, it did so in part to stop publishers from oppressing authors, potential competitors, and the public").

44. See id.

45. See id:; Niva Elkin-Koren, Copyright Law and Social Dialogue on the Information Superhighway: The Case Against Copyright Liability of Bulletin Board Operators, 13 CARDOzo ARTS \& ENT. L.J. 345, 406 (1993).

46. Elkin-Koren, supra note 45 , at 407.

47. Id. at 400-11.

48. Jaszi, supra note 34 , at 300.

49. See Elkin-Koren, supra note 45 , at 407 ; Friedman, supra note 24 , at 722.

50. See, e.g., Friedman, supra note 24 , at 723-24; Jaszi, stupra note 34, at 306-07.

51. See S. 1284, 104th Cong. (1995); H.R. 2441, 104th Cong. (1995).

52. Lemley, Menell, Merges \& SAmuelson, supra note 33, at 889. 
Intellectual Property Organization's diplomatic conference in Geneva, but conferees narrowly defeated those proposals. ${ }^{53}$ Apparently commentators had wielded some influence over policy makers.

\section{Testing the Waters: Netcom Chips Away at Service Provider Liability}

The prominent case to emerge from the fray of these intense debates was Religious Technology Center v. Netcom On-Line Communication Services, Inc., where a California district court found that policy dictated a softening of strict liability for copyright infringement in the digital world. ${ }^{54}$ In Netcom, a dispute arose when defendant Dennis Erlich, a former Scientology minister, posted quotes and criticism of writings by Scientology's founder, L. Ron Hubbard, on a Usenet newsgroup. ${ }^{55}$ Religious Technology Center (RTC) owned the copyright to Hubbard's writings, and Erlich gained access to the Internet via Netcom. ${ }^{56}$ RTC sued not only Erlich, but also Thomas Klemesrud, the BBS operator, and Netcom, the Internet service provider. ${ }^{57}$

While RTC alleged direct copyright infringement by Netcom, ${ }^{58}$ and the court reeognized that direct copyright infringement carries with it strict liability, the court opined that "there should still be some element of volition or causation which is lacking where a defendant's system is merely used to create a copy by a third party." 59 The court sensed a need to protect service providers on the periphery of infringement, even if they should have known, at some level, that infringing activity was taking place. The court therefore rejected the direct infringement theory. ${ }^{60}$

Beyond rejecting direct liability for service providers, Netcom reformulated contributory infringement liability for service providers. Specifically, Netcom set out a process that adjusted the balance of burdens between service providers and copyright owners. The court recognized that "a mere unsupported allegation of infringement by a copyright owner may not automatically put a defendant on notice of infringing activity." ${ }^{\prime \prime 61}$ In this sense, the notice raises, but does not answer, the question of whether the

53. For a comprehensive analysis of how the U.S. digital agenda fared at the conference, see Samuelson, supra note 20.

54. 907 F. Supp. 1361 (N.D. Cal. 1995).

55. Id. at 1365-66. A Usenet newsgroup is a forum for discussion on a global system of distributed discussion; it is typically available over the Internet and classified hierarchically by topic. See, e.g., id. at 1366 n.4.

56. Id. at 1365-66.

57. Id.

58. Id. at 1367 .

59. Id. at 1370 .

60. Id. at 1373 (stating that direct infringement liability for service providers would sweep too broadly without adequate justification to "hold the entire Internet liable for activities that cannot reasonably be deterred").

61. Id. at 1374 . 
service provider has the adequate knowledge to be held liable for contributory infringement. ${ }^{62}$ Therefore, liability certainly does not attach before the service provider has received notice and may not even attach after that point.

Despite the indeterminate nature of the notice RTC provided Netcom, the court seemed to impose upon Netcom a duty to investigate the contents of the notification. ${ }^{63}$ For example, RTC contacted Netcom before filing suit and asked Netcom to block Erlich from accessing the system. ${ }^{64}$ After receiving the letter, Netcom did not look at the allegedly infringing postings. ${ }^{65}$ The court criticized Netcom's failure to respond, finding that its inaction "raise[d] a question as to Netcom's knowledge once it received [RTC's] letter." 66 The court's intuition was on target with its policy judgment to balance burdens: Netcom admitted that "had it looked at the copyright notice and statements regarding authorship, it would have triggered an investigation into whether there was infringement." ${ }^{167}$ Netcom failed to respond in accordance with the intended function of the notification, that is, to instill an adequate level of suspicion to induce investigation.

Lastly, Netcom stipulated that if the service provider discovers infringing material through its required investigation, it has a duty to take down that material. ${ }^{68}$ After receiving notice of RTC's infringement claim, Netcom should not be free to continue assisting the infringement of RTC's copyrighted works. ${ }^{69}$ Instead, the court reasoned that Netcom should take simple steps to disable access to the infringing material to prevent future and ongoing harm to the copyright. ${ }^{70}$

\section{II}

\section{The DMCA: Congress Adopts NetCom's Core Principles}

\section{A. The Underlying Competing Interests}

After Netcom's departure from both the White Paper and existing case law in 1995, Congress had another chance to consider the future of copyright law in the digital environment. This time, various well-formulated arguments were on the table. The digital age continued to promise unprecedented potential for education, electronic commerce, communications, and research, but Congress still had two opposing concerns. First, the ease with which users could copy and exchange information threatened

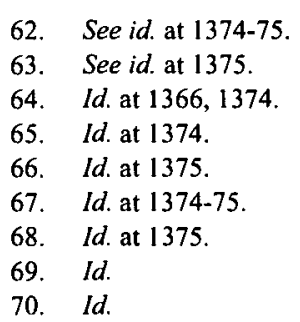


copyright owners with rampant and unchecked exploitation of their materials. $^{71}$ Without assurances of copyright protections, a copyright owner might be reluctant to subject a copyrighted work to the digital world's potential instantaneous, global distribution. Naturally, this fear of exploitation led Hollywood and other major content owners to continue advocating maintaining strict liability for service providers. ${ }^{72}$

Second, and in tension with the first concern, strict liability for copyright infringement posed a potentially debilitating threat to otherwise oblivious and preoccupied service providers, upon whom Congress depended to support the expansion of the Internet. ${ }^{73}$ Thus, while Congress sought to foster information transfers of increasingly high volume, service providers grew increasingly hesitant to expand their capabilities or to continue business at all.

With this leverage, service providers pushed Congress to immunize them from copyright violations. Given their virtual immunity in the defamation realm, ${ }^{74}$ service providers had reason for optimism. In the early I990s, defamation cases created strange incentives: to avoid liability, service providers could either take a hands-off approach or overmonitor content. ${ }^{75}$ In response, Congress passed section 230 of the Communications Decency Act in 1996 to balance these two extremes. ${ }^{76}$ However, the Fourth Circuit's broad interpretation of this section practically granted full immunity to service providers. ${ }^{77}$ Naturally, service providers were hoping to use this trend to support their immunity in the copyright realm. ${ }^{78}$

71. See, e.g., S. REP. No. 105-190, at 1-2, 8 (1998)

72. For a sense of Hollywood's intentions, see, for example, Claudia Eller \& James Bates, Congress Puts Power Behind Hollywood's Goals, L.A. Times, Oct. 23, 1998, at C1; Pamela Samuelson, A Look at ... Whose Ideas, Anyway? Facing a Pay-Per-Use Future, WASH. Post, Nov. 1, 1998 , at C3.

73. See, e.g., S. REP. No. 105-190, at 2, 8 .

74. See Paul Ehrlich, Note, Regulating Conduct on the Internet: Communications Decency Act $\S 230,17$ Berkeley TeCH. L.J. 401 (2002). Courts had previously split regarding whether to rest liability on the service provider's knowledge of the defamatory acts of its users. Compare Stratton Oakmont, Inc. v. Prodigy Servs. Co., No. 31063/94, 1995 N.Y. Misc. LEXIS 229 (Sup. Ct. May 24, 1995) (holding Prodigy strictly liable as a publisher even without knowledge of the underlying defamatory statements), with Cubby, Inc. v. CompuServe, Inc., 776 F. Supp. 135 (S.D.N.Y. 1991) (holding that CompuServe could not be liable because evidence showed that it had no actual or constructive knowledge of the defamatory statements at issue).

75. See Ehrlich, supra note 74, at 403-04.

76. 47 U.S.C. $\$ 230$ (1998 \& Supp. 2001).

77. That is, the court interpreted the Communications Decency Act (CDA) exemptions as precluding courts from entertaining claims that would place a service provider in a publisher's role. See Zeran v. Am. Online, Inc., 129 F.3d 327 (4th Cir. 1997) (holding that the CDA completely barred Zeran's defamation claim because even if AOL had notice of the defamatory statcments, it would not have a duty to remove the defamatory content on AOL's bulletin boards).

78. See, e.g., Carolyn Said, Fighting for Cyberspace Rights, S.F. CHron., April 2, 1998, at D3; Ethan Wallison, Corporate Interests Delay Global Copyright Accords, CHI. TRIB., May 10, 1998, at C5. However, this would prove to be difficult. Although immunity in the defamation context would continue to expand, the same would not be the case for copyright liability. For an analysis of the 
By 1998, Congress faced the worst of both worlds: without a clarifying statute on the books, copyright owners had an incentive to keep their materials off the Internet, and service providers had an incentive to thwart development of the Internet. To address this pair of concerns, Congress passed the Digital Millennium Copyright Act in 1998. ${ }^{79}$

\section{B. Compromise in the DMCA}

In attempting to safeguard against the threats to both copyright owners and service providers, Congress crafted a compromise to encourage cooperation between the two parties. ${ }^{80}$ Title I of the DMCA articulates protections for copyrights, to "create[] the legal platform for launching the global digital on-line marketplace for copyrighted works." 81 In response, Title II provides clarity to service providers regarding their liability for supporting this new marketplace in order to enhance the Internet's "efficiency," "quality," and "expan[sion]."82 Congress, therefore, hoped that service providers and copyright owners would meet halfway to maximize the benefits of the Internet by providing a safer environment for copyright owners to post their material and for service providers to stay in business. ${ }^{83}$

To incentivize cooperation between copyright owners and service providers, burdens for each party had to be reasonably proportional and adequately tailored to reflect the various functions of different service providers. ${ }^{84}$ For example, for service providers that are "mere conduits" for automatically transmitted material, liability is precluded irrespective of knowledge, as long as the service provider does not initiate or select the recipients of the transmission. ${ }^{85}$ In contrast, service providers that provide system caching, information storage, or information location tools may be subject to liability. ${ }^{86}$ Subsections $512(\mathrm{~b})$, (c), and (d) focus on these

divergence of service provider liability for defamation and for copyright infringement, see Jonathan Band \& Matthew Schners, Safe Harbors Against the Liability Hurricane: The Communications Decency Act and the Digital Millennium Copyright Act, 20 CARDozo ARTS \& ENT. L.J. 295 (2002); Matt Jackson, One Step Forward, Two Steps Back: An Historical Analysis of Copyright Liability, 20 Cardozo ArTs \& ENT. L.J. 367 (2002). See also Ehrlich, supra note 74, at 405-08.

79. Digital Millennium Copyright Act of 1998 (DMCA), Pub. L. No. 105-304 (1998) (codified in scattered sections of 17 U.S.C.).

80. See S. REP. No. 105-190, at 20 (1998); H.R. REP. No. 105-551, Part 2, at 49-50 (1998).

81. S. REP. No. 105-190, at 2 .

82. Id.

83. See, e.g., H.R. Conf. Rep. No. 105-796, at 72 (1998)

84. See, e.g., White Paper, supra note 15, at 122-23 (recognizing that service providers provide a variety of services under a variety of circumstances and "[n]o one rule may be appropriate").

85. 17 U.S.C. $\$ 512$ (a) (1998).

86. See id. $\S 512$ (b)-(d). Section 512 defines these functions as follows: System caching is the "intermediate and temporary storage of material on a system or network controlled or operated by or for the service provider"; information storage is the "storage at the direction of a user of material that resides on a system or network controlled or operated by or for the service provider"; and information 
specific service provider functions and stipulate notice-and-takedown procedures as well as counternotification processes. ${ }^{87}$ These provisions provide safe harbors from liability if the procedures are followed.

Incorporating Netcom's core principles, the specific notice-andtakedown provisions of the safe harbors provide a step-by-step time line whereby service providers are initially protected from the unprecedented liability that digital technology has presented. These provisions relieve a service provider from proactively having to comb through its content until it receives a copyright owner's notification alleging infringement. ${ }^{88}$ The DMCA safe harbors also shield service providers from liability for monetary damages $^{89}$ and set specified restrictions for injunctive relief. ${ }^{90}$

Following Netcom's common sense approach, the safe harbors are not impenetrable. A service provider cannot claim the safe harbor if it has actual or constructive knowledge of the underlying infringement, ${ }^{91}$ it obtains a financial benefit from the infringing activity, ${ }^{92}$ or it receives a proper notification from a copyright owner. ${ }^{93}$ Therefore, if a copyright owner believes a storage provider or an information location tool provider is contributorily infringing his works, section 512 gives him the power to attempt to oust the service provider from the safe harbor by sending proper notification. The copyright owner must provide a "written communication" to the service provider's "designated agent"94 that identifies the allegedly infringing material (or the reference or link to that material) and provides "information reasonably sufficient to permit the service provider to locate the material" (or the reference or link to that material). ${ }^{95}$ Specifically, Congress provided that the notification must include "substantially"96.

(1) the signature of the copyright owner or his agent,

location tools are "tools, including a directory, index, reference, pointer, or hypertext link" that "refer[] or link[] users to an online location." $I d$. $\S 512$ (b)(1), (c)(1), (d).

87. See id. $\S 512(\mathrm{~b})(2)(\mathrm{E}),(\mathrm{c})-(\mathrm{d}),(\mathrm{g})$.

88. See Religious Tech. Ctr. v. Netcom On-Line Communication Servs., Inc., 907 F. Supp. 1361, 1374 (N.D. Cal. 1995); H.R. REP. No. 105-551, Part 1, at 11.

89. 17 U.S.C. $\$ 512(a),(b)(1),(c)(1),(d)$.

90. Id. $\S 512(\mathrm{j})$.

91. Id. $\S 512(\mathrm{c})(\mathrm{l})(\mathrm{A})(\mathrm{i})-(\mathrm{iii}),(\mathrm{d})(\mathrm{l})(\mathrm{A})-(\mathrm{C})$.

92. Id. $\S 512(\mathrm{c})(\mathrm{l})(\mathrm{B}),(\mathrm{d})(2)$.

93. Id. $\S 512(\mathrm{c})(1)(\mathrm{C}),(\mathrm{d})(3)$.

94. Id. $\S 512(\mathrm{c})(3)(\mathrm{A})$. That is, a designated agent is someone specified:

to receive notifications of claimed infringement described in paragraph (3), by making available through its service, including on its website in a location accessible to the public, and by providing to the Copyright Office, substantially the following information: (A) the name, address, phone number, and electronic mail address of the agent[, and] (B) other contact information which the Register of Copyrights may deem appropriate.

Id. $\S 512(\mathrm{c})(2)$.

95. Id. $\S 512(\mathrm{c})(3)(\mathrm{A})(\mathrm{iii}) ;$ see also id. $\S 512(\mathrm{~d})(3)$.

96. Id. $\S 512(\mathrm{c})(3)$; see ALS Scan, Inc. v. RemarQ Cmtys., Inc., 239 F.3d 619, 625 (4th Cir. 2001). 
(2) identification of the allegedly infringed copyrighted work or a representative list of multiple works that are allegedly infringed,

(3) identification of the allegedly infringing material and information to enable the service provider to locate it,

(4) reasonably sufficient contact information of the copyright owner,

(5) a statement of good faith regarding the allegation of unauthorized infringement, and

(6) a statement of certification of the letter's accuracy. ${ }^{97}$

A service provider's response to the notification depends on how closely the notification complies with these articulated requirements. If a service provider receives a substantially compliant notification, it is required to abide by section 512's takedown provisions in order to stay within the safe harbor.$^{98}$ Namely, the service provider must remove expeditiously the allegcdly infringing material, or block access to it. ${ }^{99}$ However, if the notification received is not sufficiently compliant, that notification is not automatically evidence of knowledge that may exclude the service provider from the benefits of the safe harbor. ${ }^{100}$ If the service provider receives a technically noncompliant notification, it must help the copyright owner comply with the section 512 notification requirements. ${ }^{101}$ Otherwise, the copyright owncr can use the notification against the service provider to help establish enough knowledge to take it out of the safe harbor. ${ }^{102}$

Congress anticipated the possibility that service providers might take down more material than that which is truly infringing. Therefore, section 512 lays out a counternotice scheme to enable the alleged infringing user to participate in the process and get his content back up on the Internet. ${ }^{103}$ If a service provider who takes down material in good faith follows these counternotice provisions, it is generally protected from claims based on that takedown, even if the material taken down turns out to be noninfringing. ${ }^{104}$

By addressing each party's most serious concern and assigning burdens according to areas of expertise, Title II of the DMCA "preserves strong incentives for service providers and copyright owners to cooperate

\footnotetext{
97. 17 U.S.C. $\$ 512(\mathrm{c})(3)(\mathrm{A})(\mathrm{i})-(\mathrm{vi})$.

98. Id. $\S 512(\mathrm{c})(1)(\mathrm{C}),(\mathrm{d})(3)$.

99. Id.

100. Id. $\S 512(\mathrm{c})(3)(\mathrm{B})(\mathrm{i})$.

101. Id. $\$ 512(\mathrm{c})(3)(\mathrm{B})(\mathrm{i})$, (ii).

102. Id; see, e.g., Hendrickson v. eBay, Inc., 165 F. Supp. 2d 1082, $1084-92$ (C.D. Cal. 2001) (noting that plaintiff's refusal to comply with eBay's requests for proper information to constitute a compliant notification only harmed his own cause because the court could not use plaintiff's noncompliant notifications to establish knowledge of infringement).

103. See 17 U.S.C. $\$ 512(\mathrm{~g})$.

104. Id. $\S 512(\mathrm{~g})(1)$.
} 
to detect and deal with copyright infringements that take place in the digital networked environment." 105 A copyright owner is most able to recognize his or her own works. In addition, presumably only the copyright owners with adequate concern about the dissemination of their works will have the motivation to find infringements and notify the appropriate service provider. On the other hand, the copyright owner is unable to block access to the infringing material; only the service provider has control to thwart ongoing unauthorized dissemination. Therefore, the notice-andtakedown approach aims to capitalize on core competencies while keeping burdens balanced.

\section{Congress's Deliberate Distinction: Notice Versus Knowledge}

\section{Notice Generates Duty to Investigate}

The well-crafted process laid out in section 512 delays the service provider's duty to investigate content on its system until duly warned of the infringement claim. As Congress articulated, the problem was too much liability, not the lack thereof. ${ }^{106}$ Congress's worry was not a new ability of service providers to hide behind technology to distance themselves from direct infringcment, but rather the massive amount of information passing through a gIobal, easily accessible, and largely anonymous system.

While Congress rejected direct liability for service providers, section 5I2's notification procedures give rise to a duty to investigate the notifications of infringement claims that they receive. After all, the legislative history makes clear that the goal of notice was to enable the service provider "to find and examine the allegedly infringing material expeditiously."107 Thus, while service providers do not have to initiate investigations, they do have a duty to investigate specific claims described in the notifications from copyright owners.

\section{Contrasting Knowledge for Purposes of Contributory Infringement}

This duty to investigate is only one step along the way to establishing knowledge for contributory infringement. Congress expressly stated that, through section 512's arrangement of balanced burdens, it aimed to make it more difficult, not easier, to find a service provider liable for copyright infringement. ${ }^{108}$ Thus, although Congress decided to leave developed copyright case law as it stood, it created the safe harbors that were logically necessary to further the interests of both service providers and copyright

105. S. REP. No. 105-190, at 20 (1998).

106. See H.R. REP. No. 105-551, Part 1, at 11 (1998).

107. Id. Part 2, at 55.

108. Id. Part 1 , at 11 (explaining that the DMCA makes criteria for finding contributory infringement or vicarious liability "clearer and somewhat more difficult to satisfy"). 
owners. ${ }^{109}$ If a service provider were deemed ineligible for an existing safe harbor, its liability would then be evaluated based on the existing doctrines of copyright law. ${ }^{110}$ This bifurcated analysis suggests that a service provider's notice of a claim pursuant to section 512 does not automatically establish knowledge for purposes of contributory infringement.

In general, contributory infringement aims to hold a party accountable for the acts of a third party. Liability is supported by "the basic common law doctrine that one who knowingly participates in or furthers a tortious act is jointly and severally liable with the prime tort-feasor." 111 Although the copyright statute does not articulate a rule for contributory liability in the infringement context, courts have applied the general principle of intermediary liability to the copyright realm. ${ }^{112}$ Because a copyright owner is the sole authority who can allow others to exploit his copyright, any exploitation by an outside party is necessarily unauthorized.

As in other realms of tort liability, courts apply contributory copyright infringement doctrine where it is "just." 113 For example, in Sony Corp. $v$. Universal City Studios, Inc., the United States Supreme Court stated that "vicarious liability is imposed in virtually all areas of the law, and the concept of contributory infringement is merely a species of the broader problem of identifying the circumstances in which it is just to hold one individual accountable for the actions of another."114 The doctrine essentially aims to punish parties whose actions serve to promote or buttress the infringing activity. ${ }^{115}$

To be found liable for participating in the copyright infringement, a defendant must, "with knowledge of the infringing activity, induce[], cause[] or materially contribute[] to the infringing conduct of another."116 Although courts separate their analysis of contributory infringement into issues of knowledge and material contribution, both elements are necessary to establish contributory infringement. ${ }^{117}$ For example, one may materially contribute to an underlying infringement by providing a stage for an improper public performance of a copyrighted work without knowing that the

109. Id. (following Netcom and its progeny and overruling "aspects of [Playboy Enterprises, Inc. v. Frena], insofar as that case suggests that such acts by service providers could constitute direct infringement" (citation omitted)).

110. See id.

111. Screen Gems-Columbia Music, Inc. v. Mark-Fi Records, Inc., 256 F. Supp. 399, 403 (S.D.N.Y. 1966).

112. See, e.g., Sony Corp. of Am. v. Universal City Studios, Inc., 464 U.S. 417, 434-35 (1984).

113. See id. at 435 .

114. Id.

115. See A \& M Records, Inc. v. Napster, lnc., 239 F.3d 1004, 1019 (9th Cir. 2001) (citing Matthew Bender \& Co. v. West Publ'g Co., 158 F.3d 693, 706 (2d Cir. I998)).

116. Gershwin Publ'g Corp. v. Columbia Artists Mgmt., Inc., 443 F.2d 1159, 1162 (2d Cir. 1971); see also Fonovisa, Inc. v. Cherry Auction, Inc., 76 F.3d 259, 264 (9th Cir. 1996).

117. See 3-12 NimMER ON COPYRIGHT, supra note 4, § 12.04[A][2][a] (quoting Gershwin, 443 F.2d at I 162). 
performer was not authorized to perform the work publicly. The mandatory pairing of these two elements-knowledge and material contributionindicates that the contributory infringer must participate with some awareness of his own connection to the infringing activity. ${ }^{118}$

When considering the knowledge element, courts require the defendant to have actual or constructive knowledge of the underlying direct infringement. ${ }^{119}$ The significant addition of a knowledge requirement in the contributory context, not present in suits against direct infringers, requires the resolution of many more questions of fact. Consequently, copyright owners may face a procedural setback and be unable to take advantage of summary judgment. ${ }^{120}$ Furthermore, the knowledge requirement raises not only issues of fact, but also uncertainty as to what a court will require to satisfy it. ${ }^{121}$

A challenging case for determining sufficiency of knowledge was Sony. ${ }^{122}$ In that case, entertainment companies sued Sony for selling video cassette recorders (VCRs) to consumers, some of whom would use the machines to infringe copyrights. ${ }^{123}$ The Court was unwilling to hold Sony liable for copyright infringement because it was providing a product that was "capable of substantial noninfringing uses." 124 Another court characterized this analysis as a reluctance of the Sony Court to "imput[e] knowledge of possible infringements." ${ }^{125}$ As applied to the digital environment, while a service provider likely knows that some subscribers will commit copyright infringement over the Internet, a "substantial" number of noninfringing uses may also exist. ${ }^{126}$ Just as a VCR manufacturer cannot possibly know all the ways consumers will use its products, a service provider cannot predict which and how many of its users will commit copyright infringement. However, this analysis leaves open the possibility that if the service provider were privy to additional information regarding infringing activity but did not disable the offending material's display, it could be held liable for contributory infringement with the requisite level of knowledge.

118. See id.

119. See A \& M Records, Inc. v. Napster, Inc., 114 F. Supp. 2d 896, 918 (N.D. Cal. 2000) (citing Cable/Home Communication Corp. v. Network Prods., Inc., 902 F.2d 829, 846 (11th Cir. 1990); Sega Enters. Ltd. v. MAPH1A, 948 F. Supp. 923, 933 (N.D. Cal. 1996)), aff'd in part, rev'd in part, 239 F.3d 1004 (9th Cir. 2001); see also Gershwin, 443 F.2d at 1162.

120. See, e.g., Weiskopf, supra note 11 , at 16.

121. See id.

122. See Sony Corp. of Am. v. Universal City Studios, Inc., 464 U.S. 417 (1984).

123. See id. at $419-20$.

124. Id, at 456 .

125. See CoStar Group Inc. v. LoopNet, 1nc., 164 F. Supp. 2d 688, 697 (D. Md. 2001). The district court's concern parallels that of Congress when it was constructing the DMCA's safe harbors.

126. See Alfred C. Yen, Internet Service Provider Liability for Subscriber Copyright Infringement, Enterprise Liability, and the First Amendment, 88 GEO. L.J. 1833, 1873-74 (2000). 
In a clearer example of what constitutes sufficient knowledge, the California district court in $A \& M$ Records, Inc. $v$. Napster, Inc. found evidence showing that Napster had both actual knowledge and actual notice. ${ }^{127}$ Napster executives admitted that "facilitating the unauthorized exchange of copyrighted music was a central part of Napster, Inc.'s business strategy from the inception." 128 Moreover, Napster received communications from the Recording Industry Association of America (RIAA) regarding more than 12,000 infringing music files. ${ }^{129}$

However, the contributory infringement doctrine "does not require [defendant's] actual knowledge of specific acts of infringement." the court found that Napster had constructive knowledge of direct infringement, even though Napster did not know the precise times and titles of infringing files. ${ }^{131}$ Similarly, with this constructive knowledge already present, it was no longer relevant that the defendant's knowledge of the direct infringement was difficult to obtain because it "[could not] distinguish infringing from noninfringing files." 132 This low evidentiary standard marks a sharp distinction from the specificity required to constitute notice under the DMCA's safe harbors. ${ }^{133}$ Thus, to determine the knowledge for contributory infringement, the court looks for a general state of awareness that the intermediary has ignored; this ignorance results in the service provider's consciously or constructively allowing infringing activity to continue unbridled.

In the recent case In Re Aimster Copyright Litigation, even though no facts on record explicitly showed actual knowledge, the court pieced together evidence to establish constructive knowledge sufficient for contributory infringement liability. ${ }^{134}$ For example, plaintiffs, which were several record company copyright owners, repeatedly notified Aimster, the operator of a file sharing service, about alleged infringement that Aimster's system enabled. ${ }^{135}$ In addition, Aimster's service included not only a "Guardian Tutorial" to teach users how to infringe copyrighted material but also chat rooms and bulletin boards where users openly

127. 114 F. Supp. 2d 896, 918 (N.D. Cal. 2000), aff'd in part, rev'd in part, 239 F.3d 1004 (9th Cir. 2001).

128. Id.

129. Id.

130. Id. (citing Gershwin Publ'g Corp. v. Columbia Artists Mgmt., Inc., 443 F.2d 1159, 1163 (2d Cir. 1971)).

131. Id.

132. See A \& M Records, Inc. v. Napster, 1nc., 239 F.3d 1004, 1020 (9th Cir. 2001). Compare this contributory infringement context with the safe harbor context where distinguishability is relevant because the copyright owner must provide either information specific enough to allow the service provider to locate the allegedly infringing material or a link to that specific material.

133. See text accompanying notes 94-97.

134. 252 F. Supp. 2d 634, 649-51 (N.D. 111. 2002).

135. Id. at $638-39,650$. 
discussed their infringing activity. ${ }^{136}$ Lastly, Aimster encouraged and aided infringement of "Top 40" songs through its "Club Aimster."137

As in Napster, the Aimster court did not require specificity of knowledge. ${ }^{138}$ Therefore, the court rejected Aimster's defense that its system, which encrypted data flowing between its users' computers, made it impossible to identify exactly which files its users transmitted. ${ }^{139}$ The court reasoned that Aimster itself implemented the encryption scheme and, in any event, plaintiffs provided screen shots that showed "unequivocally" particular users in possession of specific files. ${ }^{140}$ Thus, Aimster's ability to identify the users, not the specific materials allegedly being infringed, was enough for the court to establish the knowledge requirement for contributory infringement.

In sum, the court in Aimster sought to punish Aimster for willfully ignoring the general information it possessed regarding infringement. ${ }^{141}$ The doctrine of intermediary liability for copyright infringement exists precisely to hold parties accountable for continuing to allow abuse of plaintiffs' copyrights. Contrary to a duty to investigate based on section 512 notice, the court did not allow Aimster to take additional time to consider whether infringement was actually occurring; Aimster had already lost its chance to take down offending material before its contributory liability came into effect.

III

\section{Confusion in the Case Law: The Different Approaches Since CONGRESS Adopted SECTION 512}

\section{A. The Conflation of Knowledge and Notice}

Even after Congress codified the reasoning in Netcom, courts still had trouble distinguishing their analysis of knowledge for contributory infringement from that of safe harbor eligibility. Some courts have blended the analysis of knowledge for contributory infringement and notice under section 512 without ostensibly providing independent analyses. For example, in Perfect 10, Inc. v. Cybernet Ventures, Inc., a California district court found likely contributory infringement and summarily noted that an inability to invoke the safe harbor would follow. ${ }^{142}$ This imputation is troublesome because the safe harbor is meant to protect potential contributory

\footnotetext{
136. Id. at 650 .

137. Id.

138. See id. at 651 .

139. See id. at 650-51.

140. See id. at 651 .

141. See also Sony Corp. of Am. v. Universal City Studios, Inc., 464 U.S. 417 (1984) (finding that the presence of substantial noninfringing uses mitigated against the Court's need to punish Sony).

142. 213 F. Supp. 2d 1146, 1169-71, 1179-80, 1182 (C.D. Cal. 2002).
} 
infringers from liability. ${ }^{143}$ Perfect 10 , which operates a Web site and magazine featuring photos of nude women, sued Cybernet, a competitor of Perfect $10 .{ }^{144}$ Cybernet runs an online age verification system called "Adult Check," ${ }^{145}$ which, according to Perfect 10 , had search and link capabilities to allegedly infringing sites. ${ }^{146}$ The court forgave Perfect 10 's failure to notify Cybernet of alleged infringement before filing suit because third parties had already notified the defendant repeatedly. ${ }^{147}$ Moreover, Cybernet itself had a team that reviewed and approved of sites regularly. ${ }^{148}$ In general, the court seemed to discount Cybernet's various defenses because its "prior invective" did not reflect genuine attempts to "work[] to address potential problems with its affiliated sites." 149

After finding likely success for Perfect 10 on the contributory infringement knowledge requirement, the court more cursorily addressed whether Cybernet qualified for the safe harbor in section 512. The court analyzed the issues in this order because "[s]ection 512 does not affect the elements of copyright liability. Instead, it affects the remedies available for any infringement which might be found."150

Regarding safe harbor eligibility, the court did not focus on the actual notification, but instead found fault with Cybernet's notification receipt process. ${ }^{151}$ Cybernet's stated structure was not only inflexible, but also misleading. Rather than helping copyright owners make their noncompliant notifications become compliant, Cybernet's process confused them as to what the true section 512 requirements were. ${ }^{152}$ For example, Cybernet's policy rejected representative lists, even though section 512(c)(3)(A)(ii) expressly approves of them. ${ }^{153}$ It also required the use of internal Web sites where the specific copyrighted work appears. ${ }^{154}$ Perhaps due to Cybernet's arguably manipulative and underhanded behavior, the court offered a lessthan-full exploration of Cybernet's safe harbor eligibility. In any event, it failed to acknowledge any intended relief of the safe harbor scheme.

143. Presumably the safe harbor is in place to protect service providers who truly are potential contributory infringers. In that sense, it is worthwhile for the court to evaluate safe harbor eligibility first to prevent consideration of contributory infringement liability from tainting that evaluation of eligibility and thereby eliminating any effectiveness of the safe harbor's intended protection.

144. Perfect 10,213 F. Supp. 2d at $1156,1164-65$.

145. Id. at 1158 .

146. Id. at $1156,1158-59,1162,1165$.

147. Id. at 1169 (noting that Cybernet received approximately 2,000 email communications from the Association for the Protection of 1nternet Copyright and subsequent notification from users).

148. See id. at 1169-70.

149. Id. at 1169 n. 14 .

150. Id. at 1179 .

151. Id. at 1179-80.

152. Id. at 1180 .

153. Id.

154. Id. 
Inversely, in Arista Records, Inc. v. MP3Board, Inc., the court found that a notification letter could provide the actual knowledge necessary for contributory infringement solely because it complied with section 512 notification requirements. ${ }^{155}$ A number of record companies sued MP3Board, an operator of a Web site that allows Internet users to locate audio files from various other Web sites. ${ }^{156}$ The record companies claimed that many of these audio files were pirated copies of the record companies' copyrighted material. ${ }^{157}$

While no actual music files were availablc directly on the MP3Board site, MP3Board acted as a search engine to find files on other sites and provided tutorials to assist users in this process. ${ }^{158}$ In addition, MP3Board enlisted users to expand its listings: users could post links on the MP3Board site to other sites that contained audio files. ${ }^{159}$ MP3Board also provided a link to Freedrive, a third party's site that enabled users to store their audio files online. ${ }^{160}$

Furthermore, MP3Board's site provided a forum for message boards, where users could post questions or song requests to which other users or MP3Board staff could reply. ${ }^{161}$ MP3Board staff participated actively in these message boards: They responded to users' posted requests by personally searching for links to songs and posting the links on the message board. They also summoned users to supply the work that another user had requested and established a password system to provide users access to selected music files. ${ }^{162}$

The RIAA initially notified AbovcNet Communications, Inc., the service provider that connected MP3Board's site to the Internet, ${ }^{163}$ and Metromedia Fiber Network, Inc., the corporate successor of AboveNet, but to no avail. ${ }^{164}$ The RIAA then notified MP3Board directly and insisted upon the removal of all infringing links from MP3Board's site within a week. ${ }^{165}$ The communication named twenty-two song titles to serve as representatives of infringed titlcs and included marked-up printouts of screen shots of MP3Board's site that identified 662 links that allegedly led to material that was infringing the record companies' copyrights. ${ }^{166}$ Because

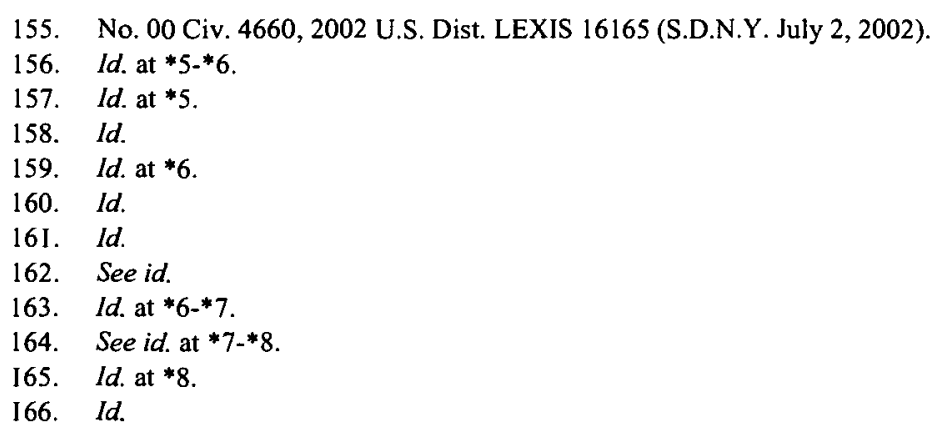


MP3Board did not disable access to the identified links, despite the letter, the RIAA filed suit against MP3Board. ${ }^{167}$

The court in MP3Board focused on MP3Board's ability to locate the allegedly infringing material in the abstract, but did not consider that MP3Board would need time to locate and evaluate that material. Furthermore, the court did not evaluate MP3Board's understanding of the scope or nature of the infringement. ${ }^{168}$ Lastly, the court never independently asked whether MP3Board possessed knowledge sufficient to meet the level of contributory infringement knowledge. As a result, the court truncated to nothing MP3Board's window of opportunity to investigate the notice of claim, which essentially set an expectation for MP3Board to search its content before receiving a letter of notification.

The conflation of the knowledge requirement with notification compliance, in both Perfect 10 and MP3Board, cancels out the benefit of the safe harbor provisions of the DMCA. Neither case fulfills Congress's intent to protect service providers initially from the dangers of direct liability in the digital environment via carefully crafted notice-and-takedown provisions.

\section{B. Independent Analysis of Knowledge and Notice}

Safe harbor ineligibility and contributory infringement liability do not necessarily form an inseparable pair. While most courts have exhibited difficulty in forging independent analyses for the knowledge element of contributory infringement and notice under section 512, the Fourth Circuit in ALS Scan, Inc. v. RemarQ Communities, Inc. came close: it applied the nascent notification requirements of the DMCA before it addressed the contributory infringement knowledge requirement. ${ }^{169}$ However, the court's analysis made short shrift of the warning period allowed in the safe harbor notification context. ALS Scan, Inc., an adult photograph producer and marketer, sent a cease-and-desist letter to RemarQ Communities, Inc., an Internet service provider. ${ }^{170}$ The letter complained that some of RemarQ's 24,000 subscribers were violating ALS Scan's trade name and copyrights, and accused RemarQ of purposely creating the newsgroups to infringe ALS Scan's registered copyrights. ${ }^{171}$ It also claimed that virtually all of the images in the newsgroups were infringing in nature. ${ }^{172}$ To prove its point, ALS Scan identified Web sites that published its photographs without its

167. Id. at*8-*9.

168. Cf. H.R. REP. No. 105-551, Part 2, at 55 (noting that it is important for the service provider to gain an "understand[ing of] the nature and scope of the infringement being claimed").

169. ALS Scan, Inc. v. RemarQ Cmtys., Inc., 239 F.3d 619, 620, 625-26 (4th Cir. 2001).

170. Id. at $620-21$.

171. Id.

172. Id. 
authorization as well as Web site addresses that provided explanations of ALS Scan's copyrights. ${ }^{173}$

RemarQ refused to comply with the letter's requests to take down immediately the allegedly infringing sites. ${ }^{174}$ Nonetheless, it did communicate its willingness to remove infringing postings as soon as ALS Scan sufficiently and individually identified the infringing postings. ${ }^{175}$ ALS Scan retorted that the sheer number of images and the length of time for which infringement had been occurring made willful infringement crystal clear. ${ }^{176}$ At an impasse, ALS Scan filed suit demanding injunctive relief as well as actual and statutory damages. ${ }^{177}$ Among other defenses, RemarQ claimed protection under the DMCA's safe harbor provisions and discounted ALS Scan's notification attempts as inadequate to preclude the safe harbor protection. ${ }^{178}$

The district court found that ALS Scan's notification did not substantially comply with two of the six notice elements undcr section 512(c)(3)(A): it did not include a representative list of the infringing items on RemarQ's site, and it did not provide enough information for RemarQ to identify and locate the infringing material ALS Scan wanted RemarQ to remove. ${ }^{179}$ Thus, the copyright owner did not overcome the threshold to trigger an investigation by RemarQ, and RemarQ remained in the safe harbor, unless independent actual or constructive knowledge of infringement could be established.

By contrast, the Fourth Circuit's approach focused more on the reasonableness built into the safe harbor provisions to protect copyright owners from overly burdensome notification requirements. ${ }^{180}$ Because the court framed its analysis by noting that the safe harbor provisions aimed to protect only "innocent" service providers that could prove they lacked actual or constructive knowledge of the infringement, the court implied that the "substantially" compliant notification provided a basis for RemarQ's knowledge. ${ }^{181}$ Apparently, the notification option is no different from the other knowledge-based routes that can force RemarQ out of the safe harbor

\footnotetext{
173. Id. at 620,625 .

174. Id. at 621 .

175. Id.

176. Id.

177. Id.

178. Id.; see also supra text accompanying notes 88-102 (detailing notification requirements under 17 U.S.C. \& 512).

179. ALS Scan, 239 F.3d at 624 .

180. See id. at 625. For additional analysis of ALS Scan and the Fourth Circuit's reasonableness approach, see Pearson Liddell, Jr. \& William D. Eshee, Jr., Substantial Notice Under the Digital Millennium Copyright Act, 8 Tex. Wesleyan L. Rev. 379 (2002).

181. ALS Scan, 239 F.3d at 623-25. That is, RemarQ is not innocent; therefore, RemarQ had actual or constructive knowledge. Yet this alone would expel RemarQ from the safe harbor. See also Liddell \& Eshee, supra note 180 , at 390 \& n. 105.
} 
and shift the burden to RemarQ to terminate the infringing postings. ${ }^{182}$ Thus, the court seemed to dispense with the possibility of a middle-ground warning-and-investigation period for RemarQ after it was notified of ALS Scan's claim. ${ }^{183}$ Ultimately, the court reversed the district court's summary judgment in favor of RemarQ regarding the notification's compliance ${ }^{184}$ and found that issues of fact remained regarding RemarQ's willful ignorance of the continuing infringement. ${ }^{185}$

In Hendrickson v. eBay, Inc., the court more clearly expressed the distinction between actual or constructive knowledge and notification compliance. ${ }^{186}$ In that case, eBay, which provides an online forum where individuals can buy and sell consumer goods and services via an auction or for fixed prices, received a letter from plaintiff Robert Hendrickson. ${ }^{187}$ The letter mentioned Hendrickson's copyright to the documentary film Manson, which was allegedly offered for sale in DVD format on eBay's Web site without Hendrickson's permission. ${ }^{188}$ The letter also insisted that eBay "cease and desist 'from any and all further conduct considered an infringement(s) of [Plaintiff's] right' or else face prosecution 'to the fullest extent provided by law.","189

After receipt of this letter, eBay promptly attempted to help Hendrickson provide proper notice, under section 512 of the DMCA, on at least two occasions. ${ }^{190}$ However, Hendrickson refused to comply with eBay's suggestions or to participate in eBay's Verified Rights Owner program whereby eBay offers customer support, priority email status, and search assistance to copyright complainants, such as Hendrickson. ${ }^{191}$

The court analyzed whether eBay qualified for the safe harbor in the DMCA as a prerequisite to addressing the issue of whether eBay "[could] be held secondarily liable for providing the type of selling platform/forum

182. See ALS Scan, 239 F.3d at 624-26; Liddell \& Eshee, supra note 180, at 390. Liddell \& Eshee observe:

[O]nce ALS Scan showed the court enough evidence to prove that the information provided

to RemarQ gave RemarQ actual or constructive knowledge of the infringing activity and that

RemarQ failed to prevent the infringement, the court was satisfied that the substantial

notification requirements were met for the purposes of the motion for summary judgment. Id. (footnotes omitted).

183. Cf. Hendrickson v. eBay, lnc., 165 F. Supp. 2d 1082, 1092-94 (C.D. Cal. 2001) (noting that the requirement of no actual or constructive knowledge in safe harbor is a separate question from notification compliance).

184. ALS Scan, 239 F.3d at $625-26$.

185. See id.

186. 165 F. Supp. 2d at 1087-90, 1092-94.

187. Id. at 1084 .

188. Id.

189. Id. at 1084-85 (citation omitted) (alteration in original).

190. See id. at 1085 (noting that eBay urged Hendrickson to follow procedures set out in the DMCA by precisely identifying the allegedly infringing items and providing a statement under penalty of perjury of copyright ownership, for example).

191. Id. 
and services that it provided, however limited or automated in nature, to sellers of counterfeit copies of the film "Manson." "192 When determining whether the letter gave eBay enough information to locate the allegedly infringing material, the court gave weight to the surrounding circumstances. $^{193}$ For example, in order for eBay to be able to identify "unauthorized" copies of Manson, it would need access to specific item numbers. ${ }^{194}$ Moreover, this identifying information would have to appear within the section $512(\mathrm{c})(3)(\mathrm{A})$ written communication. ${ }^{195}$

Despite the unclear notification, which the court held to be noncompliant, eBay "voluntarily searched its website on a daily basis for all copies of 'Manson' in DVD format, removed all such listings and suspended repeat offenders." ${ }^{196}$ Clearly, eBay was not taking advantage of the DMCA safe harbor, as it was imposing a burden on itself to search its Web site, the very action from which the safe harbors are meant to shelter a service provider, such as eBay. ${ }^{197}$ After finding that Hendrickson's letter did not substantially comply with the notification requirements in section 512 , the court granted summary judgment to eBay on the copyright claims. ${ }^{198}$ Here, the safe harbor was fully able to protect eBay. Moreover, even a noncompliant warning instilled enough suspicion in eBay to trigger an investigation.

\section{Hazy Analysis Somewhere in Between}

Despite commendable intentions, it can be difficult for a court to separate cleanly its analysis of contributory infringement knowledge from its evaluation of section 512 notification compliance. The court in CoStar Group Inc. v. LoopNet, Inc. attempted to consider knowledge and notification independently, but one inquiry blurred into the other. ${ }^{199}$ The court found that LoopNet, a provider of an Internet posting service for commercial real estate for lease, could not be charged with knowledge for contributory infringement before receiving notification, ${ }^{200}$ and thus indicated that the notification is at least relevant to, if not dispositive of, infringement

192. Id. at 1087 .

193. Id. at 1090 .

194. Id.

195. See id. at 1090-91 (noting that Hendrickson claimed that he communicated to eBay that all DVD copies of Manson are unauthorized, although that notification occurred after suit had been filed).

196. Id. at $1091 \mathrm{n} .9$ (citation omitted).

197. It is likely that eBay simply conducted a risk assessment and concluded that it was worthwhile to initiate searches after receiving communications from Hendriekson but before receiving a legally compliant notification. Nonetheless, section 512's codification stipulates a process that applies to all service providers, even those that would not have assessed risks on their own accord as eBay probably did.

198. Id. at 1094.

199. 164 F. Supp. 2d 688 (D. Md. 2001).

200. Id. at $692,698-99$. 
liability. Plaintiff CoStar, a commercial real estate information provider, claimed that once LoopNet received its letter, it knew about the continuing infringing activity. ${ }^{201}$

The court in CoStar first addressed contributory infringement liability independent of the safe harbor. The court noted the difficulty of finding constructive knowledge before CoStar's letter regarding alleged infringement by LoopNet's users, because those users could have been licensed. ${ }^{202}$ After receipt of CoStar's letter, however, issues of fact arose regarding LoopNet's level of knowledge. ${ }^{203}$ Although the court did not rule whether the letter imputed knowledge sufficient for contributory infringement liability, echoing the similar reluctance of the Supreme Court in Sony, the notification provided the only impetus to consider that possibility.

Next, the court officially tackled safe harbor eligibility. Because LoopNet did not contest the compliance of CoStar's notification, the court went straight to analyzing LoopNet's compliance with the takedown provisions. ${ }^{204}$ The court did acknowledge that "proof that LoopNet had knowledge of ... the infringements [is a] necessary element[] of CoStar's contributory infringement claim ... [but this element is] slightly different from those applicable to LoopNet's safe harbor defense and so require[s] a separate determination if LoopNet fails to remain in the safe harbor."205 However, the court allowed the source of notification to affect the determination of knowledge by essentially using the compliance test for notice under section 512 as a proxy for a sufficient level of knowledge for contributory infringement.

ln conclusion, these cases illustrate that application of the section 512 safe harbors is decidedly mixed. Some courts, like those in Perfect $I 0$ and MP3Board, have blended the analysis of knowledge for contributory infringement and notice for safe harbor ineligibility to allow one determination to drive the other. In contrast, the courts in ALS Scan and Hendrickson have more successfully delineated between the different concepts. Ultimately, the end result of this varied jurisprudence may be an increased number of cases like CoStar, where courts adopt a hazy approach akin to confusion.

201. Id. at $691-92,698$.

202. Id. at 698 (relying on Netcom's reasoning that any "colorable claim" of noninfringement for the underlying user eliminates the possibility of knowledge capable of establishing the service provider's liability).

203. Id.

204. Id. at 703 .

205. Id. at 702-03. 


\section{IV \\ Distinguishing Notice of Claim and Notice of Actual INFRINGEMENT}

\section{A. Shared Features of Knowledge for Contributory Infringement and Notice for Safe Harbor Ineligibility}

Although notice in the safe harbor context serves a different purpose than knowledge in the contributory infringement context, courts may be inclined to conflate them because the two concepts share some common features. First, both contributory infringement and notification requirements operate to enable intermediary liability in the first place. It seems "just" to hold a party to a higher standard when that party is informed, at some level, about another related party's unlawful activity. In the same way that a contributorily liable service provider actually knows or has reason to know of a user's infringing activity, a notified service provider has a heightened awareness that infringing material could be present.

Most important to the copyright owner, both types of notice give some control to the copyright owner over how to proceed with a claim. For example, both doctrines allow the copyright owner to choose whom to hale into court. Because copyright is a strict liability offense, ${ }^{206}$ the direct infringer will always be subject to suit. However, if direct infringement were the only option, copyright owners would likely face difficulty in realizing the redress they seek. The intermittent or anonymous presence of many Internet users makes individual suits seem futile. Additionally, because many users may only infringe one time or copy one file, the sheer number of copyright infringers may dishearten a potential plaintiff enough to prevent him from filing suit. Lastly, even after expending time and effort to find and identify each direct infringer, a copyright owner may find that many such defendants either are not reachable by a court or do not have the means to compensate a recording conglomerate for its costs and damages that allegedly result from the infringements en masse. ${ }^{207}$ It is not surprising, then, that even though knowledge is required in suits against intermediaries, many copyright owners choose to pursue vicarious and contributory infringement claims against a known, centralized, and presumably wellfunded service provider to process a copyright claim in one fell swoop.

In addition, copyright owners can expand the possibilities of suits simply by serving a notification that substantially complies with section 512 requirements upon a service provider. ${ }^{208}$ In this way, the copyright owner opens the prospect of obtaining money damages from a scrvice provider for contributory infringement if no investigation and appropriate

206. See, e.g., Religious Tech. Ctr. v. Netcom On-Line Communication Servs., Inc., 907 F. Supp. 136I, 1367 n. 10 (N.D. Cal. 1995).

207. See Weiskopf, supra note I1, at 10-11.

208. See 17 U.S.C. $\$ 5 I 2(c)(I)(C)$, (d)(3) (I 998$)$. 
takedown occurs. Thus, both section 512 notification and the contributory infringement knowledge element give the copyright owner some choice as to how he will proceed to uphold his copyrights.

Second, as litigation is unpleasant and inconvenient even for the most seasoned litigants, both third-party liability and spelled-out notification requirements bring some structure and certainty to an otherwise unwieldy process. If the copyright owner can point to actual facts that establish that the intermediary knew or should have known about the infringing activity, then the knowledge requirement for third-party liability is met. Likewise, if a copyright owner complies with all of the section 512 notification requirements, the burden to act in response automatically shifts to the service provider. Both doctrines provide an elegant approach to solving an otherwise messy copyright infringement problem.

\section{B. Crucial Functional Differences Dwarf Similarities}

Notably, as stated above, the DMCA did not alter existing law pertaining to contributory liability, but instead carved out safe harbors to adjust the doctrine to address particular problems that arise in the digital environment. ${ }^{209}$ It follows that Congress intended some important differences between the two systems, one judge-made and the other statutory. ${ }^{210}$

First, the timing of each notification is different. Whereas potential contributory infringers under a strict liability regime should daily search for and evaluate infringements with which they may be associated, Congress believed this was too much to ask of service providers. ${ }^{211}$ Therefore, Congress pushed into the future the moment in time when a service provider has constructive knowledge for purposes of the notification scheme. If the safe harbor did not exist, knowledge would impute to a service provider much earlier. Through this safe harbor scheme, Congress clearly decided to structure shared responsibilities between copyright owners and service providers. Importantly, the notification scheme gives service providers an opportunity to search content with an eye toward what to look for, based on the copyright owner's trained eyc, rather than searching for a needle in a haystack. ${ }^{212}$

Second, a related distinction is the type of knowledge that the service provider must possess to fall into one category or the other. Knowledge for purposes of contributory infringement refers to a service provider's knowledge of actual infringement, while notification communicates to a service

209. See H.R. REP. No. 105-551, Part 1, at 11.

210. See Yen, supra note 126, at 1872 (noting that "contributory liability is a judge-made doctrine that supplements the apparent contours of the copyright statute"). Otherwise, Congress presumably would not have been willing to enter into the morass of debates surrounding the DMCA.

211. See S. REP. No. 105-190, at 19-20.

212. See id. at 20 (stressing the importance of cooperation between service providers and copyright owners). 
provider a claim of alleged infringement. Long-standing judge-made doctrine requires an additional establishment of knowledge, actual or constructive, before holding a third party liable for the actions of another. ${ }^{213}$ If knowledge were not required in order to hold intermediaries liable, all exchanges of information, infringing and noninfringing, would prematurely fall together because the intermediary would be driven to overpolice content or go out of business. ${ }^{214}$ Even worse, users would have an incentive to continue to infringe copyrights if they knew that the service provider that posted their content would be the sole target of the copyright owner's infringement claims. However, these concerns arise only if some subscriber activity is actually infringing. On the other hand, a simple but sufficient notification only tells the service provider about claimed infringement. Although the notification should spark an investigation regardless of whether the activity complained of is truly unauthorized, the service provider's knowledge of the infringement is necessarily tentative until it conducts that investigation.

Third, the underlying goal of each type of notice is different. Contributory infringement seeks to punish a party for knowingly continuing to assist infringement; section 512 notification aims to provide an effective warning to give rise to a duty to investigate. This distinction flows naturally from the timing difference stated above. By the time contributory infringement liability is established, it is too late for the service provider to search for and remove offending material. Direct infringement has already been found, as has knowledge of the underlying infringement. ${ }^{215}$ However, notification occurs before the service provider has been otherwise clued in to the allegedly infringing material's existence. At this juncture, the service provider will need time to locate the material, make a judgment as to its legality, and take action according to that judgment. ${ }^{216}$

Fourth, and lastly, the specificity of knowledge required is drastically different in each context. No specificity of knowledge is required in the contributory infringement realm. In contrast, the notification requirements impose a high burden on the copyright owner to provide very specific

213. See Screen Gems-Columbia Music, Inc. v. Mark-Fi Records, Inc., 256 F. Supp. 399, 403 (S.D.N.Y. 1966); supra notes $113-19$ and accompanying text.

214. See supra text accompanying notes $34-45$.

215. It is useful here to compare an injunction scenario where contributory liability is already found, but only to the extent of material about which the service provider already knows. One of the purposes of the injunction is to prevent future acts of infringement. Therefore, in Napster and Aimster, the court required the copyright owner to notify the service provider of additional particular infringing material, and at that point the service provider could decide what to do. Presumably, if the material were indecd infringing and the service provider failed to disable access to it, the service provider would then be in contempt of the court order.

216. Of course, a compliant notification sufficient to render a service provider ineligible for the safe harbor must provide adequate information to enable the service provider to locate the specific allegedly infringing material. 
information to the service provider. Because the service provider is not expected to cull through its pages constantly, it needs detailed directions when it is called upon to search its content. In this sense, the safe harbors provide an important and sizable protection for service providers. After all, if notification is the only means through which a given service provider can obtain knowledge or awareness of infringing activity, then that service provider can remain in the safe harbor until the copyright owner himself has enough knowledge to communicate the exact nature of his complaint. ${ }^{217}$

\section{Framework for Analysis to Achieve Legislative Goals}

The goal of the safe harbor notification is to give the service provider enough information to "find and examine the allegedly infringing material expeditiously" and to "understand the nature and scope of the infringement being claimed." ${ }^{18}$ Congress intended the safe harbors to relieve service providers not only from searching their content, but also from determining whether any material on their systems is infringing in nature. Thus, when courts impute knowledge for contributory infringement purposes from a compliant notification, the understanding of the claimed infringement's scope and nature is missing until the service provider has had that opportunity to investigate. This crucial goal of the safe harbor notification requirements should remain intact and should be distinctly respected. ${ }^{219}$

In addition, the questions should be kept separate because of the high probability that one judgment will affect the impartiality of the other. The statute's language even addresses this potential problem expressly: failure to qualify for a safe harbor under section 512 "shall not bear adversely upon the consideration of a defense" of the service provider. ${ }^{220}$ It follows that no analysis of knowledge in the contributory infringement context should be tainted by a previous determination of a service provider's safe harbor ineligibility based on a notification, nor vice versa.

Because of these important distinctions, it is a useful tool to think of section 512 notification as "notice of claim" and knowledge sufficient for

217. Consider also the interplay between subsections (i) and (ii) of section 512(c)(3)(B), supra text accompanying notes $100-102$.

218. See H.R. ReP. No. 105-551, Part 2, at 55.

219. Congress expressed this desire for the service provider to understand the nature and scope of the infringement when it approved representative lists as sufficient for notification purposes in certain circumstances, such as "where a party is operating an unauthorized Internet jukebox from a particular site." Id. In most instances, however, a more detailed notification is likely required to enable the service provider to gain an understanding of the nature and scope of the infringing activity.

220. 17 U.S.C. \$ 5I2(1); see also Jennifer Bretan, Note, Harboring Doubts About the Efficacy of \$ 512 Immunity Under the DMCA, 18 Berkeley TECH. L.J. 43, 60-62 (2003) (noting the possible dangers of allowing infringement liability analysis to precede evaluation of safe harbor eligibility). 
contributory infringement as "notice of actual infringement."221 "Notice of claim" incorporates all of the ideas outlined above. First, it is preliminary in nature. Second, it is tentative, not final. ${ }^{222}$ The notice of claim instills a concrete suspicion in the service provider. Third, its goal is to incite action, ${ }^{223}$ either preventative or exploratory, and not to punish. In a way, it is a type of intimidation that is likely to effect a desired change. Lastly, because a warning almost always is given to a party who does not understand the problem his action is causing, the notice of claim must provide explicit and specific information to the recipient to enable that party to redress his behavior.

On the other hand, "notice of actual infringement" refers to all of the aspects of knowledge for purposes of contributory infringement mentioned above. First, it is final in nature: the infringement has already indeed occurred and the knowledge pertains to that past action. Second, the service provider knows or has reason to know that the material is actually infringing. Third, because of the concreteness and finality of the knowledge, the goal of the doctrine is to punish and deter the contribution to the infringement. Lastly, the necessary knowledge is on a general scale, presumably because of its established pervasiveness and clarity. ${ }^{224}$

A service provider that has been properly found liable for contributory infringement has, by definition, made a decision to ignore the knowledge or red flags. ${ }^{225}$ This concept demonstrates classic constructive notice. ${ }^{226}$ The willful blind eye is at the root of intermediary liability and should stay in that realm. While the DMCA left the contributory liability doctrine intact, it created new safe harbors to protect service providers that do not already know about any infringement and that respond appropriately to substantially compliant notices of claims. ${ }^{227}$

221. The structure of this proposed framework was inspired in part by Alan Latman, "Probative Similarity" as Proof of Copying: Toward Dispelling Some Myths in Copyright Infringement, 90 Colum. L. Rev. 1187 (1990).

222. See H.R. REP. No. 105-551, Part 1, at 11 .

223. See S. REP. No. 105-190, at 1-2, 8 (recognizing that imposing a duty to search before notification could threaten the viability and expansion of the Intemet). A notification will prod the service provider to perform, on a targeted scale, the searching for copyright infringement that would otherwise be required and occur for all information in a nondigital environment before notification.

224. See In re Aimster Copyright Litig., 252 F. Supp. 2d 634, 651 (N.D. 11l. 2002).

225. This distinction encompasses the volitional element discussed in Netcom. See, e.g., 3-12B NIMMER ON COPYRIGHT, supra note $4, \S 12 \mathrm{~B} .01$ [A][1].

226. See id.; Religious Tech. Ctr. v. Netcom On-Line Communication Servs., Inc., 907 F. Supp. $1361,1369-70$ (N.D. Cal. 1995).

227. See 17 U.S.C. $\$ 512$ (1998). 


\section{Benefits of Administering the Analytical Framework}

\section{Upholding Due Process}

Due process is a concept that permeates our entire judicial system. ${ }^{228}$ Adequate notice is undoubtedly a component of procedural due process. ${ }^{229}$ In the context of a contributory infringement claim, Congress created, in effect, a heightened due process with the safe harbors to increase the difficulty of finding knowledge. ${ }^{230}$ Notification is just one way to lose eligibility for the safe harbor protections. The other is to acquire actual or constructive knowledge. ${ }^{231}$ Therefore, the notification requirement must satisfy some independent meaning from actual or constructive knowledge, unless Congress has enacted surplusage. ${ }^{232}$ Furthermore, that independent meaning must be something less than what comprises actual or constructive knowledge. Otherwise, the notification provision would be subsumed into the knowledge provision.

Imputing a broader notion of knowledge from the narrower standard of knowledge that a notification imparts circumvents a service provider's opportunity to take advantage of the notification process in the first place. The full intent of the process outlined in the statute is not realized if this first step toward full knowledge disappears. Therefore, the truncated process does not comport with reasonable expectations of service providers. Instead, the difference between the statutory language and the courts' application becomes a windfall for copyright owners. ${ }^{233}$

228. See, e.g., Liddell \& Eshee, supra note 180, at 389 n.94 (listing representative cases that require adequate notice, sueh as City of Chicago v. Morales, 527 U.S. 41, 56-60 (1999) (loitering ordinance); Davis v. Monroe County Bd. of Educ., 526 U.S. 629, 640 (1999) (Title IX student-onstudent sexual harassment); City of West Covina v. Perkins, 525 U.S. 234, 240-41 (1999) (police seizure of property for a criminal investigation); E. Enters. v. Apfel, 524 U.S. 498, 536 (1998) (possible guarantee of future lifetime health benefits for retirees); and BMW of N. Am., Inc. v. Gore, 517 U.S. 559, 574-75 (I996) (unexpectedly severe punitive damages)).

229. Id.

230. See I7 U.S.C. $\$ 512$ (1998).

231. Id. $\S 512(\mathrm{c})(1)(\mathrm{A}),(\mathrm{d})(1)$.

232. See, e.g., William N. Eskridge, JR. et al., Cases and Materials on Legislation: Statutes and the Creation of Public Policy 833 (3d ed. 2001) (explaining that "[u]nder the whole act rule [of statutory interpretation], the presumption is that every word and phrase adds something to the statutory command").

233. The copyright owners already receive the benefit of the doubt in the sense that a notification need only be "substantially" compliant with the requirements in section 512 . In reality, copyright owners may also already benefit from the structure of section 512 in that service providers do not have many resources to dedicate to the assessment of notifications' adequacy. For example, Google employees end up conducting a "rough-type assessment" to filter out Ietters referencing trademark instead of copyright claims, or letters that just have the name of the copyright owner. Telephone Interview with Kulpreet Rana, Director of Legal Affairs, Google, Inc. (Mar. 3, 2003). 
Moreover, the uncertainty caused by an application inconsistent with the words of the statute is equally troublesome. ${ }^{234}$ The problem here is not that the language of the law itself would cause citizens "of common intelligence [to] guess at its meaning and differ as to its application."235 However, the variety of approaches courts take when applying that language might effect the same problematic. result. Such variety imposes immense guesswork on the part of the service provider. Service providers may expend resources trying to figure out how the standards might apply to them. Yet, whatever planning they do will likely be inefficient. ${ }^{236}$ Just as Congress worried about service providers' inability to dedicate resources to search Web pages in 1998, it might not be pleased today to see additional impositions on service providers' resources to assess unclear liability standards. Even with the safe harbor provisions operating as intended, scrvice providers would face immense resource allocation constraints. ${ }^{237}$

Recognition of "notice of claim" as separate from "notice of actual infringement" will further due process by both bringing clarity to the notification provisions and providing the service provider an opportunity to respond to a notification. Conflation of the two types of notice finds the service provider liable for contributory infringement on the knowledge element based purely on actions and allegations of the copyright owner. This risk of premature liability tends to precipitate the takedown of material; this ultimately hinders Congress's desire to expand the content of the Internet. ${ }^{238} \mathrm{~A}$ notice of elaim helps dissipate such panic and gives service providers a chance to resist taking down material that is not infringing.

\section{Protecting Free Speech}

A more fundamental concern regarding hasty takedowns is the threat to free speech. Much academic literature has lambasted the DMCA for endangering free speech. ${ }^{239}$ However, protecting the full function of the safe

234. See, e.g., Michael P. Van Alstine, The Costs of Legal Change, 49 UCLA L. REv. 789, 812-15 (2002); see also Anthony D'Amato, Legal Uncertainty, 71 CALIF. L. REV. 1, 5 n.11, 8 (1983) (explaining the danger of intentionally applying only certain portions of a law).

235. See Van Alstine, supra note 234, at 812 \& n.112 (quoting Connally v. Gen. Constr. Co., 269 U.S. 385, 391 (1926), and citing Bouie v. City of Columbia, 378 U.S. 347, 350 (1964) (emphasizing "the requirement of the Due Process Clause that a criminal statute give fair warning of the conduct which it prohibits")).

236. See id. at 813 (noting that "settled rules of law provide the framework for less costly, more accurate, and thus more effective planning for future activity").

237. For example, Google rarely is able to make useful qualitative assessments of the legitimacy of notification letters because it is a hassle and because its employees are not clerks. That is, making adjudicatory decisions on the delicate fair use doctrine or other non-bright-line doctrines proves particularly difficult. Telephone Intervicw with Kulpreet Rana, supra note 233.

238. See H.R. REP. No. 105-551, Part 1, at 11.

239. See, e.g., Yen, supra note 126, at 1886-87; J.M. Balkin, Free Speech and Hostile Environments, 99 Colum. L. REv. 2295 (1999); Mark A. Lemley \& Eugene Volokh, Freedom of Speech and Injunctions in Intellectual Property Cases, 48 DukE L.J. 147 (1998); see also Patrick J. 
harbors may be the best way to control threats to free speech. For example, if a service provider knows that a compliant notification will be proof of knowledge in a subsequent case regarding contributory infringement claims, that service provider is almost undoubtedly going to take down the content without taking time to investigate. The incentive to take down content increases beyond what the plain words in the statute induce.

This risk aversion is exacerbated by the uncertainty discussed above in Part IV.D.1. ${ }^{240}$ When facing threatened liability for contributory infringement, service providers will find that relevant court decisions are too few and too erratic to delineate clearly what constitutes enough notice for intermediaries. ${ }^{241}$ Against such uncertainty, service providers are likely to acquiesce to copyright owners who take the time and effort to notify them. Service providers will be afraid that if they do not take down allegedly infringing material after receiving notification from a copyright owner, they not only will lose the safe harbor but also will be liable for contributory infringement. They will not take time to investigate, out of fear that the protection explicitly set out in the safe harbors no longer exists in practice.

It is true that service providers often take down material out of sheer convenience. When faced with severely limited resources, taking down material will always beat the alternative-complicated copyright liability lawsuits. However, it is important to uphold the Ievel of protection Congress set out in the safe harbors. It is shortsighted to insist that a critical mass of clear court cases that respect the safe harbors' warning-andinvestigation period will not instill adequate confidence within service providers to reap their intended benefits from Congress's carefully balanced burdens. Allowing service providers the opportunity to access the material first and evaluate whether it violates copyright would decrease the frequency with which service providers take down content based solely on a notification.

\footnotetext{
Carome \& Samir Jain, Immunity for Tort Liability for Online Services: Why the Decision in Zeran v. America Online is Good Public Policy, 2 No. 10 Cyberspace Law. 13, 14 (1998) (observing that "imposing liability on interactive service providers for third-party content . . would, as a practical matter, compel service providers to err on the side of censorship"); Xavier Amadei, Note, Standards of Liability for Internet Service Providers: A Comparative Study of France and the United States with a Specific Focus on Copyright, Defamation, and llicit Content, 35 CoRnell INT'L L.J. 189, 211 (2002) (noting that both U.S. and French "commentators have stressed the dangers of requiring technical intermediaries to exercise screening for content"). Business goals may add to the incentive to promote free speech. For example, Google has an incentive to preserve the integrity of its index as much as possible, so it prefers to filter as little as possible. Telephone Interview with Kulpreet Rana, supra note 233.

240. See Yen, supra note 126, at 1883 (explaining that an innocent service provider will still take down material even though there is no real prospect of liability).

24l. Id. (lamenting that lawyers cannot offer service providers "ironclad assurances" that courts will rule consistent with the service providers' beliefs regarding their liability).
} 
Another angle on the free speech defense of safe harbors is a concern regarding prior restraints on speech. ${ }^{242}$ As discussed above in Part III.A., service providers will lose their opportunity to investigate the legitimacy of notifications if the compliance of that document is conflated with the knowledge requirement for contributory infringement. Therefore, they will take down material before any verification of its infringing nature is possible. Yet, established doctrine indicates that the task of proving worthiness of censorship must be on the censor, not the party subject to censoring. ${ }^{243}$

Moreover, individual takedowns may seem minor on their own, but the Internet boasts millions of users. Each of these users is deprived of access to a means of speech if material disappears here and there. This result plainly undercuts Congress's underlying goal to expand the Internet. The burgeoning breadth of the Internet can quickly contract at the mandate of a handful of notification letters from copyright owners and the exaggerated threat of contributory infringement liability. ${ }^{244}$ This loss of information could have a devastating effect on those who rely on such information. ${ }^{245}$

\section{E. Applying the Analytical Framework}

In some instances, separately analyzing safe harbor eligibility and knowledge for purposes of contributory infringement liability with their distinct functions in mind might affect the outcome. For example, MP3Board might not have been liable for contributory infringement if the compliant notification were not used to show its actual knowledge of infringing activity. After a few noncompliant notifications, plaintiff Arista Records did send a compliant notification to MP3Board. ${ }^{246}$ However, that

242. This argument is well developed by the Electronic Frontier Foundation. See http://www.eff.org/Legal/Cases/AlsScan_v_RemarQ/20010302_eff_amicus.html (last visited Sept. 18, 2003) [hereinafter EFF].

243. See id; Freedman v. Maryland, 380 U.S. 51, 58-59 (1965) (outlining three safeguards against the dangers of censorship: the burden of proof must be on the censor, restraints before final judgment must be short-lived and must preserve the status quo, and final judicial decisions must be made promptly).

244. See EFF, supra note 242 (noting that the Netcom court found that forcing Netcom to disable the BBS's Internet access was “'overbroad, as it would unnecessarily keep hundreds of users, against whom there are no allegations of copyright infringement, from accessing a means of speech.'" (citing Netcom, 907 F. Supp. at 1377 n.24)).

245. Rosa Julià-Barceló \& Kamiel J. Koelman, Intermediary Liability in the E-Commerce Directive: So Far So Good, But It's Not Enough, 2000 Computer L. \& SeCurity ReP. 4, 231-39 (2000) (noting that copyright owners may be "merely mistaken" but the resulting takedowns are serious nonetheless). Julià-Barceló and Koelman use the example of Apple's case against Microsoft in which Apple alleged infringement of its graphical user interface in Microsoft Windows software. In that mid1980 s case, the court held that the copyrights had not been infringed. However, Julià-Barcelo and Koelman ponder what would have happened if the case arose today, under the DMCA's regime. For example, if Apple had sent a notification to service providers who disseminated Windows software, Microsoft's impending success may have been cut short by one of its most feisty competitors. Id.

246. Arista Records, Inc. v. MP3Board, lnc., No. 00 Civ. 4660, 2002 U.S. Dist. LEXIS 16165, *24-*30 (S.D.N.Y. July 2, 2002). 
notification only served as a preliminary noticc of claim. At that point, MP3Board did not know if the claimed infringement was unlawful. To find out, MP3Board would have had an opportunity to investigate the allegedly infringing material. As the court could not yet determine whether direct infringement existed, ${ }^{247}$ it is plausible that MP3Board decided the material was noninfringing. Presumably, for that reason, it did not take down the material.

The fact that MP3Board could no longer invoke the safe harbor should not change the court's analysis of contributory infringemcnt liability. First, a contributory infringement claim must establish the existence of underlying infringement. Here, that element was uncertain. Regarding the knowledge element of contributory infringement, apparently any investigation that MP3Board might have conducted did not lead to notice of actual infringement. In addition, the court was not able to determine conclusively whether MP3Board had other actual or constructive knowledge of some genuine infringement. ${ }^{248} \mathrm{MP} 3 \mathrm{~B}$ oard's failure to take down the material should not subject it to a contributory infringement claim if no knowledge of actual infringement could be established.

Letting a compliant notification serve as a notice of claim not only reflects more accurately the intentions of Congress, but also furthers the policies of due process and free speech. Under this approach, MP3Board would have been given adequate notice and opportunity to investigate, consistent with the text of the statute and, therefore, with a servicc provider's reasonable expectations. Furthermore, the content that was arguably noninfringing would have remained available until determined to be actually infringing.

In other instances, the outcome could be thc same under the model framework, but courts would benefit from a cleaner analysis nonetheless. For example, in $A L S S c a n$, the court found the notification to be compliant and remanded the issue of copyright infringement and other possible affirmative defenses of RemarQ. ${ }^{249}$ This notice of claim did not impute knowledge of actual infringement on its system, ${ }^{250}$ but rather imparted a duty to investigate.

Unlike in MP3Board, where underlying infringement was not yet established, the existence of actual infringement seemed uncontested in $A L S$ Scan. An investigation based on a notification that gave RemarQ enough information to locate the material at issue would therefore have resulted in notice of actual infringement. In turn, RemarQ's failure to take down the material subjected it to a contributory infringement claim. In any event, the

247. Id. at *10-*14.

248. Id. at *19-*30.

249. ALS Scan, Inc. v. RemarQ Cmtys., Inc., 239 F.3d 6I9, 625-26 (4th Cir. 200 I).

250. Compare id. at 625. 
court missed an opportunity to show that RemarQ should have had a window of opportunity to "detect and deal with" the allegedly infringing material ${ }^{251}$ before "los[ing] its innocence."252

Because few courts have so far had the opportunity to apply section 512, it is useful to consider a hypothetical situation involving fair use. Suppose Disney supplies a service provider with a compliant notification referring to infringing material on a third party's Web site. Of course, the notice of claim gives rise to a duty to investigate. However, upon investigation, the service provider discovers that the Web site clearly parodies a Disney character. Instead of acquiring notice of actual infringement, the service provider obtains actual notice of noninfringement because the Web site has a reasonable - and obvious - fair use defense.

A court addressing this situation would first acknowledge that the notification was a sufficient notice of claim that gave rise to a duty to investigate. It would be clear, however, that the service provider complied with that duty to investigate. During the investigation period, the court would note, the service provider had the opportunity to discover that the alleged infringement was actually a legitimate use of the copyright. ${ }^{253}$ Therefore, in the second step of the analysis, the court would have no underlying infringement on which to base the contributory infringement claim. This example most clearly illustrates the danger of imputing knowledge for contributory infringement from a compliant notification. The only way the service provider would feel free to defy Disney's notification is if it had the opportunity to discover that the material qualified as a fair use and knew that the notification would not automatically create knowledge for purposes of contributory infringement.

\section{CONCLUSION}

It is important that courts respect the warning notice that service providers are due. Although copyright infringement has been described as "the least dangerous of thefts," 254 Congress worried about the impending extraordinary liability for service providers that came with the advent of

251. Id. (quoting H.R. Conf. ReP. No. 105-796, at 72 (1998)).

252. Id.

253. See Religious Tech. Ctr. v. Netcom On-Line Communication Servs., Inc., 907 F. Supp. 1361, 1374 (N.D. Cal. 1995). The court in Netcom stated that "the lack of copyright notices on the copies, or the copyright holder's failure to provide the necessary documentation to show that there is a likely infringement" make it "beyond the ability of a [service provider] to quickly and fairly determine when a use is not infringement where there is at least a colorable claim of fair use." Id. The information contained in a compliant notification that gives rise to a duty to investigate alleviates some of these difficulties, but the investigation period must give the service provider a chance to make a judgment.

254. Yen, supra note 126, at 1892 \& n.284 (quoting "[t]he distinguished jurist Benjamin Kaplan," Benjamin Kaplan, AN Unhurried View of Copyright 78 (1967) (quoting from Voltaire, Dictionaire Philosophique, in 42 Oeuvres Completes de Voltaire 321 (lmprimerie de la Société Littéraire-Typographique ed., 1784))). 
the digital age. For example, because of the sheer volume of material to be searched, liability should arguably not take hold without the presence of "knowing assistance in that infringement." 255 In pursuit of honoring Congress's well-crafted solution of allowing safe harbors for service providers, courts can benefit from a framework that fosters precise analysis of, first, safe harbor eligibility and, second, contributory infringement liability. ${ }^{256}$ Using the term "notice of claim" will help make clear that the safe harbor notification deals with a preliminary, tentative knowledge. In contrast, when analyzing knowledge for contributory infringement liability, using the term "notice of actual infringement" will signal that the inquiry looks back and focuses on whether the service provider knew or had reason to know about an actual direct infringement and its own connection thereto.

It may seem "that [the safe harbors'] assurance of nonliability applies largely in situations where [service providers] face no liability in the first place." 257 This contention paints a separate safe harbor analysis as valueless but for the fact that the safe harbor gives the service provider control over the process of receiving complaints by designating an agent to receive them and permits avoidance of all monetary relief. ${ }^{258}$ In fact, if courts impute knowledge based on receipt of a compliant notification, they are making a dangerous world worse. After all, the DMCA already encourages "[service providers] to take an overly aggressive attitude against alleged infringers by offering the [service providers] relief from uncertainties inherent in developing law."259

A separate analysis not only furthers Congress's goal of expanding the Internet while simultaneously furthering the recognition of copyrights, but it also preserves due process for service providers consistent with the intentions behind section 512 and protects what free speech is not already threatened by the DMCA and possible contributory infringement liability. As Congress was well aware, service providers deal with immensely high volumes of content and highly technical issues on a daily basis. It is natural for them to respond to complaining notifications by taking down the allegedly infringing material to avoid liability, despite the fact that a number of

\footnotetext{
255. Id. at 1892.

256. See, e.g., H.R. REP. No. 105-551, Part 1, at 11. Congress noted:

Failure to qualify for the exemption or limitation does not mean that the provider is necessarily an infringer or liable for monetary damages. If the exemption or limitation does not apply, the doctrines of existing law will come into play, and liability will only attach to the extent that the court finds that the requirements for direct infringement, contributory infringement or vicarious liability have been met, that the conduct is not excused by any other exception or limitation, and that monetary remedies are appropriate.

Id. Beyond this bifurcated analysis, an additional method of quality control for notifications may be helpful. Notably, the notification process does not impose any subpoena-like burden on the notifying party. Telephone Interview with Kulpreet Rana, supra note 233.

257. Yen, supra note 126 , at 1883.

258. Id. at $1886-87$.

259. Id. at 1893 .
} 
the notifications are disingenuous. ${ }^{260}$ Copyrights would be more accurately protected if service providers were confident in their opportunity to investigate as part of their procedural due process.

Even if, as a practical matter, many service providers do not want to be in a position to justify why the notification letter did not establish knowledge, ${ }^{261}$ it is important to protect the due process opportunities embodied in section 512 to the fullest extent. Moreover, although a counternotification scheme exists whereby a user can contest the copyright owner's claim of infringement, users rarely invoke this statutory grant. ${ }^{262}$ To avoid the inevitable effects of paranoia among service providers, courts should return to the intent and language of the safe harbor provisions and allow duly warned service providers to rest assured in those safe harbors as they investigate a notification. Otherwise, the predicted doomsday effects of direct liability for service providers will resurface-but this time based only on a copyright owner's claim.

260. See Julià-Barceló \& Koelman, supra note 245 (stating that, in December 1999, Yahoo estimated that five to ten percent of the notifications it received were of doubtful sincerity).

261. Telephone Interview with Kulpreet Rana, supra note 233.

262. See id. 